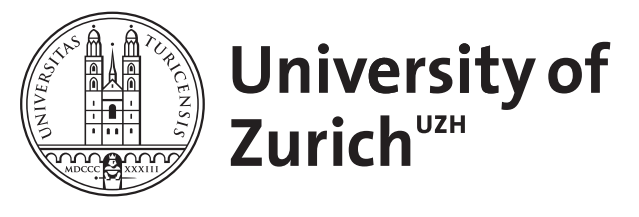

\title{
Does Money Illusion Matter?
}

\author{
Fehr, Ernst ; Tyran, Jean-Robert
}

\begin{abstract}
This paper shows that a small amount of individual-level money illusion may cause considerable aggregate nominal inertia after a negative nominal shock. In addition, our results indicate that negative and positive nominal shocks have asymmetric effects because of money illusion. While nominal inertia is quite substantial and long lasting after a negative shock, it is rather small after a positive shock.
\end{abstract}

DOI: https://doi.org/10.1257/aer.91.5.1239

Posted at the Zurich Open Repository and Archive, University of Zurich ZORA URL: https://doi.org/10.5167/uzh-95345

Journal Article

Originally published at:

Fehr, Ernst; Tyran, Jean-Robert (2001). Does Money Illusion Matter? American Economic Review, 91(5):1239-1262.

DOI: https://doi.org/10.1257/aer.91.5.1239 


\title{
Does Money Illusion Matter?
}

\author{
By ERnst FEHR AND JEAN-Robert TyRAN*
}

\begin{abstract}
This paper shows that a small amount of individual-level money illusion may cause considerable aggregate nominal inertia after a negative nominal shock. In addition, our results indicate that negative and positive nominal shocks have asymmetric effects because of money illusion. While nominal inertia is quite substantial and long lasting after a negative shock, it is rather small after a positive shock. (JEL C92, E32, E52)
\end{abstract}

Until recently, the notion of money illusion seemed to be thoroughly discredited in modern economics. James Tobin (1972) described the negative attitude of most economic theorists towards money illusion as follows: "An economic theorist can, of course, commit no greater crime than to assume money illusion" (p. 3). As a consequence, money illusion has been anathema to the profession for several decades. The index of the Handbook of Monetary Economics (Benjamin M. Friedman and Frank M. Hahn, 1990), for example, does not even mention the term "money illusion." In principle, money illusion could provide an explanation for the inertia of nominal prices and wages and, thus, for the nonneutrality of money. The stickiness of nominal prices and wages seems to be an important phenomenon (see, e.g., George A. Akerlof et al., 1996; Ben S. Bernanke and Kevin Carey, 1996; David Card and Dean Hyslop, 1997; Shulamit Kahn, 1997; Truman F.

\footnotetext{
* Fehr: Institute for Empirical Research in Economics, University of Zurich, CH-8006 Zurich, Switzerland; Tyran: Department of Economics, University of St. Gallen, CH9000 St. Gallen, Switzerland. We are particularly grateful for two excellent referee reports and for comments by George Akerlof, Linda Babcock, Jim Cox, Urs Fischbacher, Simon Gächter, Ed Glaeser, Lorenz Goette, Charles Goodhart, Reinhard Selten, Dick Thaler, Frans van Winden, and Michael Waldman. In addition, we acknowledge helpful comments by the participants of many seminars around the globe. Ernst Fehr gratefully acknowledges the hospitality of the Center for Economic Studies (CESIFO) in Munich. Valuable research assistance has been provided by Martin Brown, Beatrice Zanella, and Tobias Schneider. We are grateful for financial support by the Swiss National Science Foundation under Project No. 1214-051000.97/1, and by the EU-TMR Research Network (Project No. FMRX-CT98-0238).
}

Bewley, 1998; Alan S. Blinder et al., 1998). It has puzzled economists for decades because it is quite difficult to explain in an equilibrium model with maximizing individuals. Instead of money illusion other factors like informational frictions (Robert E. Lucas, Jr., 1972), staggering of contracts (e.g., Stanley Fischer, 1977; John B. Taylor, 1979), costs of price adjustment (N. Gregory Mankiw, 1985), and near-rationality (Akerlof and Janet L. Yellen, 1985) have been invoked to explain nominal inertia.

In this paper we do not contest the potential relevance of these explanations. We do, however, argue that money illusion has prematurely been dismissed as a potential candidate for the explanation of sluggish nominal price adjustment. Our argument is based on rigorous experimental evidence from a price-setting game that isolates money illusion from other potential determinants of nominal inertia. In particular, we show that after a fully anticipated negative nominal shock, long-lasting nominal inertia prevails, even if informational frictions, costs of price adjustment and staggering are absent. Our results indicate that the direct and indirect effects of money illusion are the major determinants of this long-lasting nominal inertia. We show, in addition, that money illusion causes much less nominal inertia after a fully anticipated positive nominal shock. This result is reminiscent of the Keynesian proposition that downward wage rigidity causes asymmetric responses to monetary shocks. Yet, since we obtain our result in a price-setting game, the asymmetric response cannot be directly related to downward wage rigidity. Our results suggest that the asymmetry is caused by a particular form of money illusion arising from people 
taking nominal payoffs as a proxy for real payoffs. After a negative money shock, nominal payoffs decline because prices tend to decline, while after a positive shock nominal payoffs increase because prices tend to rise. If these changes in nominal payoffs are taken as a proxy for changes in real payoffs there will be more reluctance to adjust prices to the new equilibrium after a negative shock.

Our experiments also allow us to judge the relative importance of the direct and indirect effects of money illusion on nominal inertia. The direct effects of money illusion are defined as those effects that are the direct result of individual optimization mistakes. The indirect effects of money illusion are defined as those effects that arise because some agents expect that others are prone to money illusion and, as a consequence, they behave differently. The distinction between the direct and the indirect effects of money illusion is important because many economists seem to believe that money illusion is not a widespread phenomenon at the individual level, i.e., that the direct effects of money illusion are small. The textbook example where all nominal prices and nominal incomes are doubled nicely illustrates this view. It is hard to believe that many people make an individual optimization mistake by choosing a different bundle of goods when prices and incomes are doubled. Our results clearly show, however, that it would be misleading to conclude that money illusion is largely irrelevant because the direct effects of money illusion are small. In our experiments the direct effects of money illusion on nominal inertia after the negative shock are also rather small but the total effects nevertheless are very large. The reason for this finding is that money illusion renders price expectations very sticky after the negative shock, whichunder conditions of strategic complementarity-induces agents to choose sticky prices. This result lends support to theories that stress that small amounts of individual-level irrationality can have large aggregate effects (Akerlof and Yellen, 1985; John Haltiwanger and Michael Waldman, 1985, 1989; Thomas Russell and Richard Thaler, 1985). It also lends support to the view of George W. Evans and Garey Ramey $(1992,1998)$ that costly expectation formation causes expectations and prices to adjust only gradually to the rational expectations equi- librium. Although there are no direct costs of forming expectations in our experiments, it is quite likely that the task of forming expectations involves cognitive costs. Taken together, the results of our experiments suggest that money illusion matters, i.e., money illusion should be considered as a serious candidate in the explanation of nominal inertia.

The rest of the paper is organized as follows: In Section I we discuss the notion of money illusion and its potential aggregate implications in more detail. In Section II we argue that experimental methods are appropriate for studying whether money illusion matters and we present our experimental design. In Section III the experimental results of the design with the negative nominal shock are presented. Section IV argues that the nature of money illusion in our experiment suggests that after a positive nominal shock there should be less nominal inertia. This conjecture is tested in a design with a positive nominal shock. In the final section we summarize and interpret our main results.

\section{Money Illusion at the Individual and the Aggregate Level}

\section{A. Money Illusion at the Individual Level}

Wassily Leontief (1936) defined money illusion as a violation of the "homogeneity postulate." This postulate stipulates that demand and supply functions are homogeneous of degree zero in all nominal prices which means that they depend only on relative and not on absolute prices. Although other authors have used slightly different definitions, the intuition behind their definitions seems to be rather similar. This intuition says that if the real incentive structure, that is, the objective situation, an individual faces remains unchanged, the real decisions of an illusion-free individual do not change either. Two crucial assumptions underly this intuition: First, the objective function of the individual does not depend on nominal but only on real magnitudes. Second, people perceive that purely nominal changes do not affect their opportunity set. For example, people have to understand that an equi-proportionate change in all nominal magnitudes leaves the real constraints unaffected. Whether people are, in fact, able to pierce the veil of money, i.e., whether 
they understand that purely nominal changes leave their objective circumstances unchanged, is an empirical question. Irving Fisher (1928), for example, was convinced that ordinary people are, in general, prone to money illusion.

More recently Eldar Shafir et al. (1997) provided interesting questionnaire evidence indicating that frequently one or both preconditions for the absence of money illusion are violated. Their results suggest that the preferences of many people as well as their perceptions of the constraints are affected by nominal values. Moreover, the answers of many people do not only indicate that they themselves are prone to money illusion but that they also expect other people's behavior to be affected by money illusion.

Since the absence of money illusion means that an individual's preferences, perceptions and, hence, choices of real magnitudes are not affected by purely nominal changes, it is natural to view money illusion as a framing or representation effect. From this viewpoint, an individual exhibits money illusion if his or her decisions depend on whether the same environment is represented in nominal or real terms. There is a large body of experimental research that shows that alternative representations of the same situation may well lead to systematically different responses (Reinhard Selten and Claus C. Berg, 1970; Amos Tversky and Daniel Kahneman, 1981). Representation effects seem to arise because people tend to adopt the particular frame that is presented and evaluate the options within this frame. Because some options loom larger in one representation than in another, alternative framings of the same options may provoke different choices.

It is important to note that the nominal representation of an economic situation is probably the natural representation for most people. This is so because most economic transactions in people's lives involve the use of money and, hence, are framed in nominal terms. Therefore, it is likely that people often perceive and think about economic problems in nominal terms which may induce money illusion. A rather basic form of money illusion occurs when people take nominal values or changes in nominal values as a proxy for real values or changes in real values, respectively. Note that this rule of thumb makes perfect sense in an environment with a given aggregate price level. However, this rule is inappropriate in situations where the aggregate price level is changing. Therefore, the application of this rule in an environment with changing aggregate prices constitutes a form of money illusion.

\section{B. Money Illusion at the Aggregate Level}

In the past, economists frequently invoked the assumption of money illusion to account for the short-run nonneutrality of money (e.g., Fisher, 1928). However, since the success of the rational expectations revolution, economists have been extremely reluctant to invoke money illusion to explain the short-run nonneutrality of money. A common feature of the models of New Classical and New Keynesian macroeconomists is that they exclusively focus on the equilibrium states of their economies. In general, they remain silent on how economic agents move from one equilibrium to the other. In models that exclusively focus on equilibrium, the assumption of the absence of money illusion is very intuitive because it is difficult to imagine that an illusion could persist in equilibrium. However, there is a strong a priori argument that money illusion is likely to affect the adjustment process of an economy after a fully anticipated monetary shock. This argument is based on the simple fact that in an interactive situation the failure of some agents to fully adjust to the nominal shock will, in general, provide incentives for other agents to not fully adjust to the shock, either. Thus, there may be a snowball effect that causes less than full adjustment for a prolonged period of time.

This can be illustrated in the context of a monopolistically competitive economy as analyzed in, for example, Akerlof and Yellen (1985) or Olivier Jean Blanchard and Nobuhiro Kiyotaki (1987). To keep the argument simple we focus solely on the firms' behavior. The reduced-form real profit function for firms in these models can be written as

$$
\pi_{i}=\pi_{i}\left(P_{i} / \bar{P}, M / \bar{P}\right), \quad i=1, \ldots, n
$$

where $\pi_{i}$ is firm $i$ 's real profit, $P_{i}$ is the nominal price set by firm $i, \bar{P}$ is the aggregate price level, $M$ denotes the supply of money, and $n$ the 
number of firms. ${ }^{1}$ In these models $M / \bar{P}$ is proportional to real aggregate demand. For simplicity, we assume identical firms, the absence of menu costs and informational frictions, and a unique and symmetric equilibrium $P_{i}^{*}=P_{j}^{*}$, for all $i, j$. In this equilibrium each firm maximizes real profits by setting $P_{i}^{*}=\bar{P}^{*}$. Since (1) is homogeneous of degree zero in $P_{i}, \bar{P}$, and $M$, a change in $M$ to $\lambda M(\lambda \neq 1)$ leads to post-shock equilibrium values of $\lambda P_{i}^{*}$ and $\lambda \bar{P}^{*}$.

Suppose now that there is one group of agents who suffers from money illusion and does, therefore, not fully adjust their nominal prices to $\lambda P_{i}^{*}$. Suppose further that there is a second group of agents that anticipates the behavior of the first group. The second group, therefore, anticipates a change in real aggregate demand $M / \bar{P}$ such that their members, in general, have an incentive to choose a price that differs from $\lambda P_{i}^{*}$, too. Whether the interaction between these groups causes aggregate nominal inertia depends in an important way on the strategic environment, that is, whether agents' actions are strategic complements or strategic substitutes. Haltiwanger and Waldman (1989) have shown that in the presence of strategic complementarity between agents' decisions, the existence of a small group of nonrational subjects can have large effects on the process of adjustment to equilibrium. In the above-mentioned model of monopolistic competition, strategic complementarity means that firm $i$ 's profit maximizing nominal price $P_{i}^{\prime}$ is positively related to the aggregate price level $\bar{P}$. This means that firms which believe that, because of money illusion, the prices of other agents are kept close to the pre-shock equilibrium have a rational reason to choose a nominal price that is also close to the pre-shock equilibrium.

Thus, under strategic complementarity rational firms have an incentive to partly imitate the behavior of the nonrational firms which gives the latter a disproportionately large impact on the aggregate price level. In contrast, in the presence of strategic substitutability, i.e., if $P_{i}^{\prime}$ is negatively related to $\bar{P}$, rational firms have an

\footnotetext{
${ }^{1}$ Equation (1) already incorporates (i) the maximizing behavior of all households, (ii) the cost-minimizing behavior of all firms for given output and wages levels, (iii) the equilibrium real wage, and (iv) the equilibrium relation between real aggregate demand and real money balances.
}

incentive to partly compensate the behavior of the nonrational ones so that the latter have a disproportionately small impact on the aggregate outcome. The results of Haltiwanger and Waldman (1989) thus suggest that, given strategic complementarity, the existence of a small group of subjects that suffer from money illusion may generate substantial nominal inertia. However, while this is a plausible theoretical argument, there is, to our knowledge, no empirical evidence for the claim that a small amount of money illusion may generate substantial nominal inertia. ${ }^{2}$

\section{An Experimental Approach to Money Illusion}

One way to rigorously examine whether money illusion matters, is to look for a natural experiment in which an exogenous and fully anticipated monetary shock occurs. In order to unambiguously identify whether the shock is fully anticipated, the researcher needs to know individual information sets before the shock. To judge whether the anticipated shock causes a disequilibrium and nominal inertia, the researcher has to know the equilibrium values of nominal prices before and after the shock. Moreover, to examine whether money illusion causes nominal inertia, the researcher should identify two similar natural experiments. In one experiment the "world" should be framed in nominal terms while in the other experiment it should be framed in real terms. In our view, it seems extremely difficult, if not impossible, to meet the above requirements with field data. In fact, the exogeneity of monetary policy and the causality between money and output is a matter of considerable debate (e.g., Christina D. Romer and David H. Romer, 1989, 1994; Kevin D. Hoover and Steven J. Perez, 1994; Wilbur John Coleman, 1996). In addition, full knowledge of the pre- and post-shock equilibrium

\footnotetext{
${ }^{2}$ Since strategic complementarity is important for our argument in favor of the aggregate relevance of (beliefs about) money illusion, one would like to know to what extent it does prevail in naturally occurring economies. Seonghwan Oh and Waldman (1990, 1994), Russell Cooper and Haltiwanger (1996), and Blinder et al. (1998) provide evidence in favor of the relevance of strategic complementarity in real economies.
} 
TABle $1-$ TReatment Conditions

\begin{tabular}{lcc}
\hline \hline & Payoffs in Real Terms & Payoffs in Nominal Terms \\
\hline Computerized opponents & $\begin{array}{c}\text { Real treatment with computerized opponents } \\
\text { (RC): } 22 \text { groups with 1 human and } n-\end{array}$ & $\begin{array}{c}\text { Nominal treatment with computerized } \\
\text { opponents (NC): 24 groups with } 1\end{array}$ \\
& 1 computerized players in each group & $\begin{array}{l}\text { human and } n-1 \text { computerized } \\
\text { players in each group }\end{array}$ \\
& & $\begin{array}{c}\text { Nominal treatment with human opponents } \\
\text { (NH): 11 groups with } n \text { human players }\end{array}$ \\
& $\begin{array}{l}\text { Real treatment with human opponents (RH): } \\
\text { 10 groups with } n \text { human players in each } \\
\text { group }\end{array}$ & in each group \\
\hline
\end{tabular}

values of nominal prices is clearly beyond the information content of presently available field data. In reality, almost all business transactions are shrouded in nominal money, i.e., it is very difficult to find real-world examples of a real frame.

In an appropriate laboratory setting, however, the above-mentioned data requirements can be met. The techniques of experimental economics allow the implementation of exogenous and fully anticipated nominal shocks and the experimenter can exert full control over pre- and post-shock equilibrium values of nominal prices. In addition, the experimenter controls the framing of the situation, e.g., whether subjects receive the payoff information in nominal or in real terms. These enhanced control opportunities suggest that laboratory experiments provide valuable information regarding the impact of money illusion on nominal inertia, which may complement and help to interpret the results of studies based on field data (for field evidence see, e.g., Michael Abbott and Orley Ashenfelter, 1976; Beth T. Niemi and Cynthia B. Lloyd, 1981). The use of experimental methods also distinguishes our examination from the study of Shafir et al. (1997). While these authors asked subjects hypothetical questions, we directly observe the evolution of individual and aggregate behavior after a nominal shock.

\section{A. General Description of the Experimental Design}

To study the impact of money illusion, we designed an $n$-player pricing game with strategic complementarity and a unique equilibrium. The pricing game was divided into a pre-shock and a post-shock phase. All $n$ players simultaneously had to determine their nominal prices in each period of the game.
They were free to change their nominal prices in each period at no cost. The players interacted anonymously via computer terminals. Each treatment condition had $2 T$ periods. During the first $T$ periods of a session the money supply was given by $M_{0}$. Then we implemented a fully anticipated monetary shock by reducing the money supply to $M_{1}$. This shock and the fact that the post-shock phase again lasted $T$ periods was common knowledge.

Our major interest concerns subjects' pricing behavior in the post-shock phase. The pre-shock phase serves the purpose to make subjects acquainted with the computer terminal and the decision environment. In addition, and more importantly, the pre-shock phase allows us to see whether subjects reach equilibrium in the pre-shock phase. After all, one can only argue that money illusion is a disequilibrating force if equilibrium has in fact been reached before the shock.

The real payoff of subject $i, \pi_{i}$, is given by

$$
\pi_{i}=\pi_{i}\left(P_{i}, \bar{P}_{-i}, M\right) \quad i=1, \ldots, n
$$

where $P_{i}$ denotes $i$ 's nominal price, $\bar{P}_{-i}$ represents the average price of the other $n-1$ group members while $M$ denotes a nominal shock variable (money supply). The nominal payoff of subject $i$ is given by $\bar{P}_{-i} \pi_{i}$. In total, we have four treatment conditions and the payoff functions (2) are the same in all conditions. The four conditions differ along two dimensions (see Table 1). The first dimension concerns the framing of the situation, i.e., whether payoffs are represented in real or in nominal terms. In the real treatments, denoted by RC and RH, subjects received the payoff information in real terms while in the nominal treatments, denoted by $\mathrm{NC}$ and $\mathrm{NH}$, payoffs were represented in nominal terms. Thus, to compute their real payoffs in the 
nominal treatments subjects had to divide their nominal payoffs $\bar{P}_{-i} \pi_{i}$ by $\bar{P}_{-i}$.

The second dimension concerns the fact whether our experimental subjects face $n-1$ preprogrammed computerized players or whether they face $n-1$ other human subjects. The crucial point here is that in the computerized condition where one human subject faces $n-1$ preprogrammed computers, the subject is informed about the aggregate response rule of the computers in advance. The response rule of the computers is given by the best replies of the computers [based on the computers' payoff functions (2)]. Therefore, there is no strategic uncertainty and, hence, no need to form expectations about the behavior of the other players in this condition. Moreover, since the computers play best replies, their behavior rules out any money illusion or any other form of irrationality. In contrast, in the condition with human opponents each subject faces the task of forming expectations about the other players' price choices. This necessarily also involves a guess about the extent to which other players are affected by money illusion.

The conditions with computerized players essentially boil down to individual decisionmaking experiments in which human subjects can maximize their money earnings by playing optimally against the known aggregate best reply of the $n-1$ computerized players. Note that in the computerized conditions the indirect effects of money illusion, which operate via the expectations that other players are affected by money illusion, can play no role because the computers play best reply. These conditions, therefore, allow us to examine to what extent money illusion has direct effects on nominal inertia, i.e., to what extent it simply causes individual optimization mistakes. In the conditions with human opponents the indirect effects of money illusion can, in addition, also play a role.

The experimental design in Table 1 allows to isolate various potentially important determinants of nominal inertia. In the $\mathrm{RC}$, money illusion is ruled out at the individual and, hence, also the aggregate level. Therefore, if we observe in the RC a slow adjustment of the nominal price chosen by the human subject after the shock, money illusion cannot be the source of this nominal inertia. Thus, with the help of the
$\mathrm{RC}$ we can test the hypothesis whether there are individual-level irrationalities other than money illusion.

In the $\mathrm{NC}$, in contrast, money illusion can affect the behavior of individuals because as a part of the individual optimization problem human subjects have to correctly deflate nominal payoffs at the various $\left(P_{i}, \bar{P}_{-i}\right)$ combinations. Hence, by comparing the post-shock prices of human subjects in the RC and the NC we can observe whether there exists money illusion at the individual level.

In the $\mathrm{RH}$, as in the $\mathrm{RC}$, individual-level irrationality other than money illusion can play a role. However, in the RH the adjustment to the new post-shock equilibrium is not just an individual optimization problem for the human subjects. In the RH, adjustment to the new equilibrium also involves the solution of a complex coordination problem. ${ }^{3}$ It cannot be taken for granted that subjects instantaneously succeed to act according to the new post-shock equilibrium. A plausible reason for this is that the complexity of subjects' task is greater in the $\mathrm{RH}$ compared to the RC.

The $\mathrm{RH}$ and the $\mathrm{RC}$ are used to examine to what extent individual-level irrationalities, other than money illusion, together with the coordination problem contribute to nominal inertia. The difference in price adjustment between the $\mathrm{RH}$ and the RC measures the impact of the coordination problem plus the impact of the interaction between the coordination problem and the individual irrationalities that are not related to money illusion. Interaction effects occur when these individual irrationalities cause slow adjustment by some subjects after the shock which-due to strategic complementarity-induces the other subjects to adjust slowly, too. A particularly interesting case arises if we find no nominal inertia in the $\mathrm{RC}$ while in the RH nominal inertia prevails. In this case all of the nominal inertia in the RH can be attributed to the coordination problem because individual

\footnotetext{
${ }^{3}$ There is an important literature on coordination problems in macroeconomic models (see, e.g., Cooper, 1999) that is based on the existence of multiple equilibria. We use the term "coordination problem" in a different way because, even in the case of a unique equilibrium, subjects face a coordination problem: Nash-equilibrium play presupposes that subjects have coordinated (equilibrium) expectations.
} 
irrationalities (other than money illusion) are absent.

In the NH, subjects face the same coordination problem as in the RH. We are, however, particularly interested in the impact of adding the nominal frame to this coordination problem, i.e., in a comparison of the $\mathrm{NH}$ and the $\mathrm{RH}$. This comparison allows us to isolate the total effects of money illusion in an environment where subjects face a coordination problem. The total effects of money illusion in this environment consist of the direct effects of individual-level money illusion as exhibited in the NC plus the indirect "multiplier" effects of individual-level illusion. These "multiplier" effects may arise because in our setting with human opponents, subjects with money illusion can also affect the expectations and thus the behavior of the subjects without money illusion. If, for example, some subjects exhibit money illusion by taking (variations in) the nominal payoff as a proxy for (variations in) the real payoff, adjustment to equilibrium in the $\mathrm{NH}$ may be slower than in the $\mathrm{RH}$. The reason is that after a negative shock, adjustment requires a decrease in nominal prices. By definition, a decrease in nominal prices is associated with a decrease in nominal payoff numbers in the NH. Therefore, subjects who exhibit the above form of money illusion mistakenly believe that real payoffs decrease with lower nominal prices. Thus, they prefer to stay at higher nominal prices, which may have a direct adjustment-reducing effect. Moreover, if some subjects believe that others suffer from this form of money illusion, they have an incentive to slow down adjustment, too. In the $\mathrm{RH}$, in contrast, this effect cannot occur because payoffs are represented in real terms. In the RH, it is, therefore, completely transparent that general price reductions are not associated with lower real payoffs.

If the deviation from the post-shock equilibrium is larger and lasts longer in the $\mathrm{NH}$ compared to the $\mathrm{RH}$, we have support for the hypothesis that money illusion contributes to nominal inertia. If, in addition, the price expectations are more sticky in the $\mathrm{NH}$ than in the $\mathrm{RH}$ we have an indication for indirect effects because the indirect effects become effective via sticky expectations. However, our design also enables us to isolate the indirect effects of money illusion at the behavioral level. The dif- ference in the deviations of the post-shock average prices from equilibrium between the $\mathrm{NC}$ and the $\mathrm{RC}, \Delta P^{N C}-\Delta P^{R C}$, measures the aggregate impact of individual-level money illusion on nominal inertia. Note that $\Delta P^{N C}-$ $\Delta P^{R C}=P^{N C}-P^{R C}$ because the equilibrium price is identical across conditions. The difference between the $\mathrm{NH}$ and the $\mathrm{RH}, \Delta P^{N H}-$ $\Delta P^{R H}=P^{N H}-P^{R H}$, measures the total effects of money illusion which consist of the individual-level effects plus the indirect effects. Thus, if there are no indirect effects of money illusion the total effects must be equal to the individual-level effects: $P^{N H}-P^{R H}=P^{N C}-$ $P^{R C}$. If there are, however, indirect effects we should observe that $P^{N H}-P^{R H}>P^{N C}-$ $P^{R C} \cdot 4$

\section{B. General Properties of the Payoff Functions}

Before we proceed to the specific numerical parameters of our experiment, it is useful to provide a general description of the payoff functions (2). They have the following properties:

(i) They are homogeneous of degree zero in $P_{i}$, $\bar{P}_{-i}$, and $M$.

(ii) The best reply is (weakly) increasing in $\bar{P}_{-i}$.

In addition, our functional specification ${ }^{5}$ of equation (2) implies that the equilibrium

(iii) is unique for every $M$,

(iv) is the only Pareto-efficient point in payoff space, and

(v) can be found by iterated elimination of weakly dominated strategies.

\footnotetext{
${ }^{4}$ Note also that if there are no individual irrationalities other than money illusion, $\Delta P^{R C}=0$, and the condition for the existence of indirect effects, $\Delta P^{N H}-\Delta P^{R H}>$ $\Delta P^{N C}-\Delta P^{R C}$, can then be written as $\Delta P^{N H}>\Delta P^{R H}+$ $\Delta P^{N C}$. This means that if the deviation from equilibrium in the $\mathrm{NH}$ condition is larger than the summed deviations in the RH and the NC condition, indirect effects prevail.

${ }^{5}$ The functional form is presented in the Appendix. Readers who are interested in the full set of instructions should consult the Appendix in Fehr and Tyran (2000), which can be downloaded from http://www.iew.unizh.ch/ wp/iewwp045.pdf. The instructions are also available from the authors upon request.
} 
Note that the real payoff $\pi_{i}$ does not depend on the average price $\bar{P}$ of all group members but on $\bar{P}_{-i}$. This feature makes it particularly easy to play a best reply for a given expectation about the other players' average price. If we made $\pi_{i}$ dependent on $\bar{P}$, so that $P_{i}$ affects $\bar{P}$, it would have been much more difficult for $i$ to compute the best reply (see also below). It is also worthwhile to point out that the nominal payoff for each subject $i$ is given by $\bar{P}_{-i} \pi_{i}$ and not by $\bar{P} \pi_{i}$. This makes the computation of the real payoffs from a given nominal payoff much easier because the deflator is independent of one's own price choice.

Properties (i) and (iii) above were implemented because our analysis focuses on the impact of money illusion on the adjustment process of an economy with a unique moneyneutral equilibrium $P_{i}^{*}, i=1, \ldots, n$. To see that properties (i) and (iii) imply neutrality, note that a change in $M$ from $M_{0}$ to $\lambda M_{0}$ leaves real payoffs unaffected if prices change to $\lambda P_{i}$ and $\lambda \bar{P}_{-i}$. Moreover, if $P_{i}^{\prime}, i=1, \ldots, n$, is a best reply to $\bar{P}_{-i}$ at $M_{0}, \lambda P_{i}^{\prime}$ also is a best reply to $\lambda \bar{P}_{-i}$ at $\lambda M_{0}$. Thus, $\lambda P_{i}^{*}$ for all $i$ is the post-shock equilibrium.

Property (ii) captures strategic complementarity and was implemented for the reasons given in Section I, subsection B. In our pilot experiments we initially implemented a price-setting game with monopolistic competition. However, it turned out that subjects quickly realized that under monopolistic competition cooperative gains can be achieved by out-of-equilibrium behavior. Therefore, both in the nominal as well as in the real frame, subjects systematically tried to achieve real payoff gains through outof-equilibrium behavior. Only towards the end of each phase these attempts vanished. Thus, in the pre- as well as in the post-shock phase of our pilot experiments, adjustment towards equilibrium was strongly retarded by attempts to cooperate. To remove this confound with the other sources of nominal inertia we chose payoff functions that ensured that the equilibrium was the unique Pareto-efficient point in the whole payoff space [property (iv)].

Finally, property (v) means that there is a method for finding the equilibrium that works exactly in the same way in the real as well as in the nominal frame. Note that the framing of payoffs has no impact at all on whether a par- ticular strategy is (weakly) dominated. In the real frame a (weakly) dominated strategy $P_{i}$ has (weakly) smaller real payoff numbers at any level of $\bar{P}_{-i}$. In the nominal frame a (weakly) dominated strategy $P_{i}$ has (weakly) smaller nominal payoff numbers at any level of $\bar{P}_{-i}$. Thus, to eliminate (weakly) dominated strategies in either frame, subjects only need to eliminate those strategies that have (weakly) smaller (real or nominal) payoff numbers at any given level of $\bar{P}_{-i}$. Since, in the condition with human opponents, the best-reply function and, hence, the number of (weakly) dominated strategies is exactly the same under the real and the nominal frame, there is, in the absence of money illusion, no reason why adjustment should differ across the $\mathrm{RH}$ and the $\mathrm{NH}$.

\section{Experimental Procedures and Parameters}

All major experimental parameters are summarized in Table 2. The experiment was conducted in a computerized laboratory with a group size of $n=4$. The group composition did not change throughout the whole experiment, i.e., for $2 T$ periods. In each group there were two types of subjects: Subjects of type $x$ and subjects of type $y$. Payoff functions differed among the types. This difference implied that $x$-types had to choose a relatively low price in equilibrium while $y$-types had to choose a relatively high price (see Table 2 for details). There is no particular reason for our choice of the group size because there are no strong conjectures about the net effects of a different group size. On the one hand, a larger group size enhances the chances that there are individuals with money illusion in a group. On the other hand, the relative impact of an individual on average prices becomes smaller. With regard to the heterogeneity of the players' payoff functions, the case of four different payoff functions would be the most realistic but also the most complicated case. Therefore, we went for an intermediate solution with only two types of players. $^{6}$

In the pre-shock phase of each treatment the

\footnotetext{
${ }^{6}$ The payoff functions of the two types were the same up to a parallel shift. Except for $P_{k}^{*}$ and $\bar{P}_{k}^{*}$ all parameters of the payoff function specified in the Appendix are the same for both types.
} 
TABle 2-EXPerimental Design

Representation of payoffs in the nominal frame Representation of payoffs in the real frame Group size

Information feedback in period $t$

Real equilibrium payoff

Choice variable

Length of pre- and post-shock phase in treatment with computerized opponents Length of pre- and post-shock phase in treatment with human opponents
Panel A: All Periods

$$
\begin{gathered}
\bar{P}_{-i} \pi_{i} \\
\pi_{i} \\
n=4 \\
\bar{P}_{-i}, \pi_{i} \\
40
\end{gathered}
$$

$P_{i} \in\{1,2, \ldots, 30\}$

$T=10$

$T=20$

Money supply $M_{0}$

Panel B: Pre-Shock Values

Average equilibrium price $\bar{P}^{*}$ and average equilibrium expectation for the whole group 18

Equilibrium price for type $x$

Equilibrium expectation $\bar{P}_{-i}^{e}$ for type $x$

Equilibrium price for type $y$

Equilibrium expectation $\bar{P}_{-i}^{e}$ for type $y$

\section{2}

18

21

27

15

Panel C: Post-Shock Values

Money supply $M_{1}$

Average equilibrium price $\bar{P}^{*}$ and average equilibrium expectation for the whole group

Equilibrium price for type $x$

Equilibrium expectation $\bar{P}_{-i}^{e}$ for type $x$

Equilibrium price for type $y$

Equilibrium expectation $\bar{P}_{-i}^{e}$ for type $y$

money supply was given by $M_{0}=42$ while in the post-shock phase it was given by $M_{1}=$ $M_{0} / 3=14$. In the pre-shock equilibrium the average price over all $n$ group members is given by $\bar{P}_{0}^{*}=18$ while in the post-shock equilibrium it is $\bar{P}_{1}^{*}=6$. In the treatments with human opponents both the pre- and the post-shock phase consists of $T=20$ periods while in the treatments with computerized opponents $T=$ 10. The reason for this difference was that we expected that adjustment would take longer in the presence of a coordination problem. For the purpose of comparing post-shock nominal inertia across treatments it is crucial that the required price adjustment, i.e., the difference between actual nominal prices in the final preshock period and the new post-shock equilibrium price, is roughly the same. To ensure comparable adjustment requirements across treatments we gave players more time to reach the equilibrium in the treatments with a coordination problem.

In each decision period subjects had to choose an integer $P_{i} \in\{1,2, \ldots, 30\}$. In addition, they had to provide an expectation about $\bar{P}_{-i}$ which we denote by $\bar{P}_{-i}^{e}$. Finally, subjects indicated their confidence about their expectation $\bar{P}_{-i}^{e}$ by choosing an integer from 1 to 6 where 1 indicated that the subject is "not at all confident" while 6 indicated that he or she is "absolutely confident."7 This measure of confidence can be interpreted as an indicator of subjects' perceived uncertainty about the other players' choices. Note that this uncertainty is an inevitable component of the coordination problem that subjects face in the condition with human opponents. At the end of each period each subject was informed about the actual realization of $\bar{P}_{-i}$ and the actual real payoff $\pi_{i}$ on a so-called outcome screen. In addition, the outcome screen provided information about the subject's past choices of $P_{i}$, past realizations of $\bar{P}_{-i}$, and past real payoffs $\pi_{i}$.

Subjects received the payoff information in matrix form. ${ }^{8}$ The payoff matrix shows the real and the nominal payoff, respectively, for each

\footnotetext{
${ }^{7}$ The detailed meaning attached to the numbers is: $1=$ not at all confident; $2=$ not much confidence; $3=$ not quite confident; $4=$ quite confident; $5=$ very confident; $6=$ absolutely confident.

${ }^{8}$ Appendix C of Fehr and Tyran (2000) contains the payoff matrices of $x$ - and $y$-types for all treatment conditions. See also footnote 5 .
} 
feasible integer combination of $\left(P_{i}, \bar{P}_{-i}\right)$. To inform subjects about the payoffs of the other type, each subject also received the payoff matrix of the other type. This information condition was common knowledge. The presentation of payoffs in the form of a matrix made it particularly easy to find the best reply for any given $\bar{P}_{-i}$ : The subject just had to look for the highest real or nominal payoff in the column associated with $\bar{P}_{-i} \cdot{ }^{9}$ In fact, one of the first things most subjects did after we distributed the instructions was to mark the best replies in the payoff tables.

After subjects had read the instructions, but before the start of the experiment, each subject had to solve a series of exercises (see the Appendix in Fehr and Tyran, 2000). These exercises involved the computation of their own payoff and the payoff of their opponents for given hypothetical strategy profiles. In the nominal treatments, in particular, subjects had to compute the real payoffs from their nominal payoff tables for given hypothetical strategy profiles. The subjects knew that we did not start the experiment until every participant in a session had solved all exercises successfully. All subjects were in fact able to solve the exercises. By this training procedure we wanted to rule out that subjects do not know how to properly deflate nominal values. It is quite likely that this procedure diminished the amount of individual-level money illusion in our experiment. It was motivated by the question whether a small amount of individual-level money illusion will cause long-lasting nominal inertia in the $\mathrm{NH}$ because of the indirect effects of money illusion. Obviously, the case for the relevance of money illusion is stronger if we observe large indirect effects.

In the treatments with computerized opponents, subjects received the same instructions and payoff tables as in the treatments with human opponents. In addition, subjects were informed that the decisions of the other three players in the group would be made by preprogrammed computers. Subjects received an in-

\footnotetext{
${ }^{9}$ If a subject is uncertain about the true value of $\bar{P}_{-i}$, the calculation of the best reply requires, of course, to take into account the subjective distribution of $\bar{P}_{-i}$ and not only the expectation of $\bar{P}_{-i}$. However, for simplicity, in the following we will use the term "best reply" in the sense of a best reply to the expectation of $\bar{P}_{-i}$.
}

formation sheet that informed them about the $\bar{P}_{-i}$ response of the three computers to each price choice $P_{i} \in\{1,2, \ldots, 30\}$. Fifty percent of the human subjects in these conditions were endowed with the payoff function of an $x$-player, the other 50 percent had the payoff function of a $y$-player.

At the end of the final pre-shock period the nominal shock was implemented in the following way: Subjects were publicly informed that $x$ - and $y$-types received new payoff tables. These tables were based on $M_{1}=M_{0} / 3$. Again each type received the payoff table for his own and the other type. Subjects kept the pre-shock tables and were encouraged to compare the preand post-shock tables. They were told that, except for payoff tables, everything else would remain unchanged. They were given enough time to study the new payoff tables and to choose $P_{i}$ for the first post-shock period. ${ }^{10}$ This procedure ensured that in the first post-shock period subjects faced an exogenous and fully anticipated negative nominal shock. At the beginning of this period it was also common knowledge that the experiment would last for another $T$ periods.

Before we proceed to the experimental results, it needs to be emphasized that in a given phase the number of dominated price choices is identical across all treatments. It is, however, not identical between the pre- and the postshock phase. Since the money supply is lower in the post-shock phase the number of dominated strategies is also lower in this phase. Note that the smaller number of dominated strategies in the post-shock phase is an inevitable result of the fact that the money supply is reduced while the nominal strategy space and the nominal accounting unit is kept constant. ${ }^{11}$ Due to the

\footnotetext{
${ }^{10}$ Subjects were told that they had ten minutes to study the new payoff tables and, in addition, three minutes to make a decision for the first post-shock period. Yet, almost all subjects made their decision well before the 13 minutes had elapsed. In the subsequent periods subjects also rarely exhausted their time limits.

${ }^{11}$ A change in the nominal price in the post-shock phase (i.e., at $M_{0} / 3$ ) by one unit has the same real effects as a change in the nominal price by three units in the pre-shock phase (i.e., at $M_{0}$ ). This means that if a nominal price is strictly dominated in the post-shock phase there will, in general, be three nominal prices that are strictly dominated in the pre-shock phase.
} 
differences in the number of dominated strategies a comparison of the adjustment speed across phases must take this difference into account. The higher number of dominated strategies in the pre-shock phase means, in particular, that the indirect effects of money illusion are likely to be smaller in this phase. This is so because, if a strategy is dominated, it is optimal to not play this strategy irrespective of the expectations about other players' behavior. Thus, expectations about other players' money illusion necessarily have less impact and, as a consequence, one would expect a quicker adjustment towards equilibrium in the pre-shock phase. Note also that the different number of dominated strategies across phases is not a problem for the main purpose of our research. We are not interested in comparing adjustment speed across phases but across treatments in the post-shock phase. For our purposes the crucial point is that in the post-shock phase the number of dominated strategies is identical across treatments because the only difference in the payoff tables concerns the framing of the payoffs.

\section{Results}

In total, 130 subjects participated in the experiments described in Table $1 .^{12}$ Twentytwo subjects participated in the real treatment with computerized opponents (RC) and 24 subjects in the nominal treatment with computerized opponents (NC). Eleven groups of four human subjects participated in the nominal treatment with human opponents $(\mathrm{NH})$ and ten groups in the real treatment with human opponents (RH). No subject participated in more than one treatment. Subjects were undergraduate students from different disciplines at the University of Zurich, Switzerland. They were paid a show-up fee of CHF 15 (approx. $\$ 12$ at that time) and their total earnings from the experiment were on average CHF 35 (approx. \$28) (including the show-up fee). On average, an experimental session lasted 90 minutes.

\footnotetext{
${ }^{12}$ In follow-up experiments with a positive money shock, described in detail in Section IV, another 96 subjects participated.
}

\section{A. Nominal Price Adjustment as an Individual Optimization Problem}

In this section, we address the question whether individual-level money illusion and other individual-level irrationality contribute to nominal inertia. Therefore, our discussion is constrained to the RC and the NC, where adjustment to the post-shock equilibrium is a pure individual optimization problem. Our first main result is that in the RC all subjects instantaneously adjust to the new post-shock equilibrium, i.e., nominal inertia is completely absent. Support for this claim is provided by column 1 of Table 3 and by Figure 1. Both the table and the figure show the pre- and post-shock path of the average price of all human subjects in the $\mathrm{RC}$. What is remarkable here is that, except for a few periods, the average price is exactly equal to the equilibrium price of $\bar{P}_{0}^{*}=18$ in the preand $\bar{P}_{1}^{*}=6$ in the post-shock period. Moreover, it is not just the average that coincides with equilibrium. In most periods literally all subjects play the equilibrium. This result contrasts with what we observe in the nominal frame. In the NC there is a small amount of nominal inertia since some subjects do not fully adjust prices to the new post-shock equilibrium. This claim is supported by Table 3 (column 2) and Figure 1. Both the table and the figure show that the evolution of average prices is, in general, more volatile relative to the RC. This suggests that at least some subjects in the $\mathrm{NC}$ have problems in finding the optimal solution to their maximization problem. Moreover, while in the RC all subjects instantaneously adjust their prices fully to the post-shock equilibrium, in the NC only 80 percent of the subjects do so. The rest of the subjects choose prices above the equilibrium so that in the first post-shock period the average price is by 2.1 units too high. Throughout the whole post-shock phase the NC most of the time is close but never exactly in equilibrium which contrasts again with the RC where after the second post-shock period all subjects are exactly in equilibrium almost all of the time.

These differences in post-shock adjustment also give rise to differences in the real income losses across RC and NC. Nominal inertia in the $\mathrm{NC}$ causes small but nonnegligible real income losses in the post-shock phase. In contrast, in 
Table 3-Evolution of Prices and Efficiency Losses over Time

\begin{tabular}{|c|c|c|c|c|c|c|c|c|}
\hline \multirow[b]{3}{*}{ Period } & \multicolumn{4}{|c|}{ Average Price } & \multicolumn{4}{|c|}{ Average Efficiency Loss (Percent) } \\
\hline & \multicolumn{2}{|c|}{$\begin{array}{l}\text { Computerized } \\
\text { opponents }\end{array}$} & \multicolumn{2}{|c|}{ Human opponents } & \multicolumn{2}{|c|}{$\begin{array}{l}\text { Computerized } \\
\text { opponents }\end{array}$} & \multicolumn{2}{|c|}{ Human opponents } \\
\hline & $\begin{array}{l}\text { Real } \\
\text { (RC) }\end{array}$ & $\begin{array}{l}\text { Nominal } \\
\text { (NC) }\end{array}$ & $\begin{array}{l}\text { Real } \\
\text { (RH) }\end{array}$ & $\begin{array}{l}\text { Nominal } \\
(\mathrm{NH})\end{array}$ & $\begin{array}{l}\text { Real } \\
(\mathrm{RC})\end{array}$ & $\begin{array}{l}\text { Nominal } \\
\text { (NC) }\end{array}$ & $\begin{array}{l}\text { Real } \\
\text { (RH) }\end{array}$ & $\begin{array}{l}\text { Nominal } \\
(\mathrm{NH})\end{array}$ \\
\hline-20 & & & 17.6 & 18.5 & & & 14.4 & 19.0 \\
\hline-19 & & & 18.2 & 19.3 & & & 21.5 & 14.6 \\
\hline-18 & & & 17.8 & 19.1 & & & 14.1 & 10.2 \\
\hline-17 & & & 17.7 & 19.4 & & & 9.5 & 11.7 \\
\hline-16 & & & 17.9 & 19.2 & & & 8.8 & 6.8 \\
\hline-15 & & & 18.3 & 19.1 & & & 10.8 & 13.2 \\
\hline-14 & & & 17.6 & 18.2 & & & 8.0 & 9.9 \\
\hline-13 & & & 17.9 & 18.6 & & & 8.2 & 4.2 \\
\hline-12 & & & 17.9 & 18.7 & & & 6.3 & 3.1 \\
\hline-11 & & & 17.6 & 18.3 & & & 5.5 & 7.5 \\
\hline-10 & 17.9 & 15.2 & 17.8 & 18.4 & 1.0 & 16.4 & 9.4 & 3.4 \\
\hline-9 & 18.1 & 17.0 & 17.5 & 18.2 & 0.5 & 12.6 & 3.6 & 1.6 \\
\hline-8 & 17.8 & 17.2 & 17.6 & 19.0 & 1.6 & 9.0 & 3.3 & 6.0 \\
\hline-7 & 18.0 & 18.0 & 17.7 & 18.3 & 0.5 & 3.0 & 2.4 & 1.8 \\
\hline-6 & 17.6 & 17.2 & 17.6 & 18.2 & 2.4 & 10.4 & 10.9 & 1.3 \\
\hline-5 & 18.0 & 17.7 & 18.1 & 18.3 & 0.3 & 5.4 & 7.0 & 2.7 \\
\hline-4 & 18.0 & 18.1 & 18.1 & 18.4 & 0.0 & 3.5 & 7.3 & 2.5 \\
\hline-3 & 17.8 & 16.1 & 17.6 & 18.6 & 1.3 & 12.6 & 3.7 & 2.8 \\
\hline-2 & 18.4 & 18.3 & 17.9 & 18.2 & 2.3 & 1.9 & 2.2 & 0.7 \\
\hline-1 & 18.0 & 17.0 & 18.0 & 18.2 & 0.0 & 5.3 & 0.9 & 0.9 \\
\hline 1 & 6.0 & 8.1 & 9.1 & 13.1 & 0.0 & 10.4 & 51.8 & 65.1 \\
\hline 2 & 7.0 & 7.4 & 7.7 & 12.9 & 3.6 & 8.2 & 20.0 & 47.5 \\
\hline 3 & 6.0 & 6.8 & 7.4 & 11.4 & 0.0 & 4.4 & 15.0 & 34.8 \\
\hline 4 & 6.0 & 6.4 & 6.9 & 10.4 & 0.6 & 6.5 & 9.1 & 27.4 \\
\hline 5 & 6.0 & 6.9 & 7.0 & 9.9 & 0.0 & 8.0 & 14.8 & 17.4 \\
\hline 6 & 6.0 & 6.8 & 6.6 & 10.2 & 0.0 & 15.6 & 7.7 & 15.9 \\
\hline 7 & 6.0 & 7.5 & 6.3 & 9.7 & 0.0 & 9.3 & 4.5 & 16.4 \\
\hline 8 & 6.0 & 6.8 & 6.4 & 9.1 & 0.0 & 15.5 & 4.6 & 10.7 \\
\hline 9 & 6.0 & 6.5 & 6.3 & 8.7 & 0.0 & 4.3 & 3.8 & 9.5 \\
\hline 10 & 5.9 & 6.5 & 6.8 & 8.6 & 1.6 & 3.8 & 11.0 & 13.8 \\
\hline 11 & & & 6.1 & 8.1 & & & 4.6 & 8.2 \\
\hline 12 & & & 6.2 & 7.6 & & & 3.3 & 6.4 \\
\hline 13 & & & 6.2 & 7.2 & & & 2.1 & 6.2 \\
\hline 14 & & & 6.2 & 6.9 & & & 2.8 & 4.6 \\
\hline 15 & & & 6.1 & 6.7 & & & 2.6 & 2.6 \\
\hline 16 & & & 6.1 & 7.3 & & & 2.1 & 9.6 \\
\hline 17 & & & 6.0 & 6.8 & & & 0.9 & 5.2 \\
\hline 18 & & & 6.1 & 7.2 & & & 1.8 & 14.2 \\
\hline 19 & & & 6.1 & 7.5 & & & 1.4 & 12.5 \\
\hline 20 & & & 6.2 & 7.0 & & & 3.0 & 2.4 \\
\hline
\end{tabular}

the $\mathrm{RC}$ there are no or only extremely small real incomes losses in the post-shock phase. To verify this claim we calculate by how much actual real income of player $i, \pi_{i}$, falls short of real income in equilibrium $\pi^{*}$. For this purpose we have computed $\varepsilon_{i t} \equiv\left(\pi^{*}-\pi_{i t}\right) / \pi^{*}$ for all players in each period $t$. $\varepsilon_{i t}$ is a measure of the income loss relative to the equilibrium payoff as a percentage of the equilibrium payoff. Since the equilibrium is efficient it is also a measure of the efficiency loss. Columns 5 and 6 of Table 3 present the evolution of the average value of $\varepsilon_{i t}$ over all players in the RC and in the NC. The two columns indicate that after the shock the average efficiency loss is most of the time zero in the RC and always lower than in the NC.

Taken together, the results of the treatments with computerized opponents indicate that there 


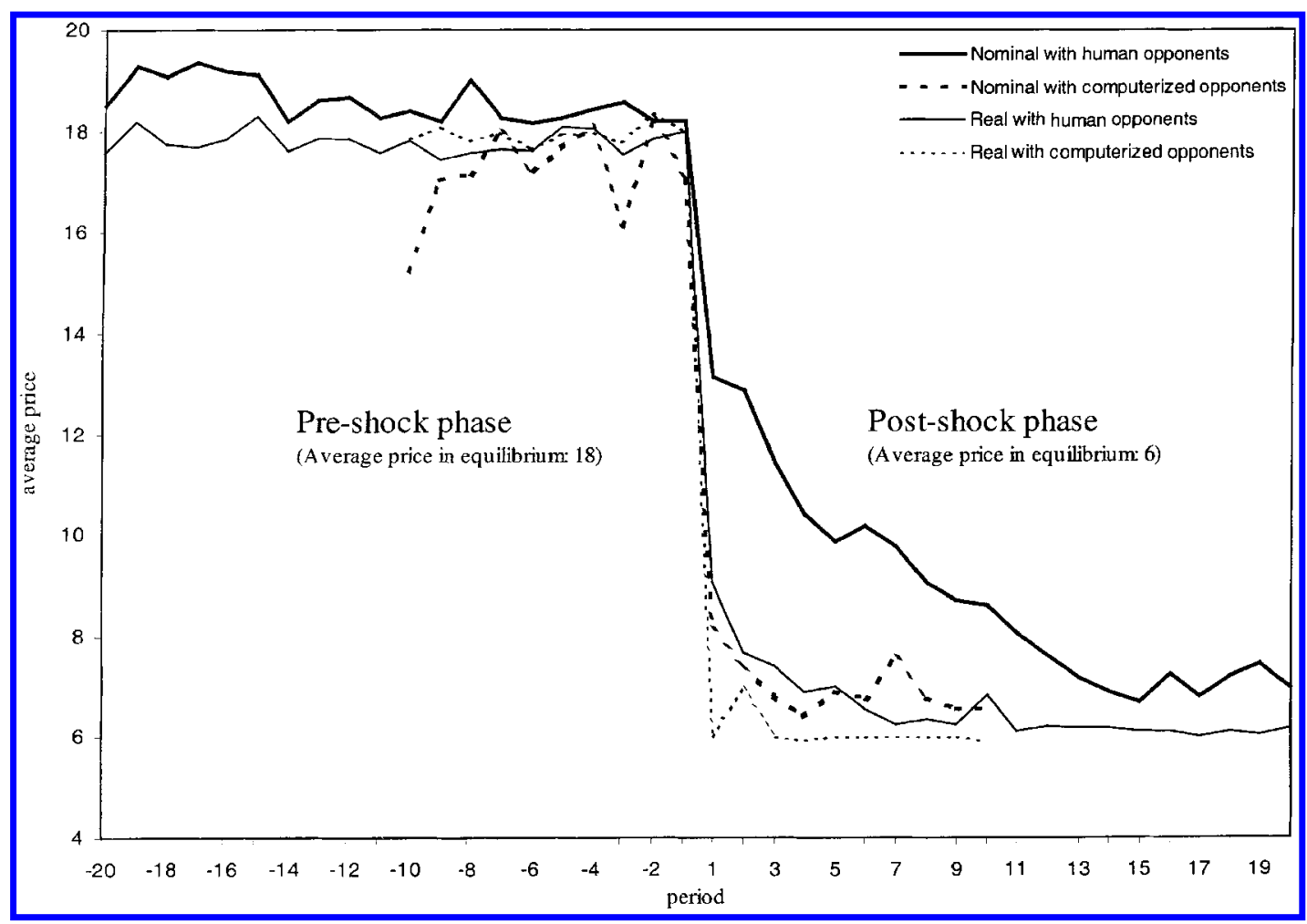

Figure 1. Evolution of Average Prices

is a small amount of money illusion at the individual level but beyond that there is no individual irrationality. The small amount of individual-level money illusion is suggested by the small price differences between the $\mathrm{NC}$ and the RC after the shock. The absence of other forms of individual irrationality is suggested by the perfect adjustment to the shock and the generally high incidence of equilibrium play in the RC.

\section{B. Nominal Price Adjustment as a Coordination Problem}

The fact that in the RC the adjustment to the post-shock equilibrium is perfect makes the interpretation of the deviation of prices from the post-shock equilibrium in the RH particularly easy. It means that the whole deviation is due to the fact that subjects in the RH face a relatively complex coordination problem. The major facts about price adjustment in the $\mathrm{RH}$ are displayed in Table 3 and Figure 1. Column 3 of Table 3 shows that in the first post-shock period average prices in the $\mathrm{RH}$ are 3.1 units above the average equilibrium price of $\bar{P}_{1}^{*}=6$. This deviation quickly decreases to 1.4 units in period 3 and after period 4 the deviation is never larger than one unit. This pattern of average behavior is not an artifact of aggregation but is also revealed at the level of individual choices. In the final preshock period 93 percent of the subjects in the RH play exactly their equilibrium strategies. In the first post-shock period only 35 percent of the subjects play the new equilibrium and 23 percent of the subjects are only one or two price units above the equilibrium. The other 42 percent are more than two units above the equilibrium. Yet, after only three periods the distribution of individual price choices has moved much closer to the equilibrium. In period 4, 45 percent of all subjects play exactly the equilibrium, 48 percent are one or two units above and only 7 percent are more than two units above the equilibrium. This post-shock evolution of prices indicates that the coordination 
problem initially causes considerable nominal inertia but that after a few periods this effect is rather small because prices are again close to the equilibrium.

Our description of the pattern of nominal inertia in the $\mathrm{RH}$ is also supported by formal statistical tests. To check how long average group prices in the $\mathrm{RH}$ and the $\mathrm{NH}$ deviate significantly from the equilibrium we ran the following regression for the post-shock phase:

$$
\bar{P}_{i t}-\bar{P}_{1}^{*}=\sum_{t=1}^{19} \alpha_{t} d_{t}+\sum_{t=1}^{20} \beta_{t}\left(1-d_{t}\right)
$$

where $\bar{P}_{i t}$ denotes the average price of group $i$ in period $t . d_{t}=1$ if the price observation in period $t$ comes from the RH. The coefficients $\alpha_{t}$ measure the deviation from equilibrium in the $\mathrm{RH}$ while the coefficients $\beta_{t}$ measure the deviation in the $\mathrm{NH} .{ }^{13}$ The results of regression (3) are summarized in Table 4 . The table shows that, at the 5-percent level, average prices in the RH deviate significantly from the equilibrium for two periods. Yet, from period 3 onwards, the hypothesis that average prices are in equilibrium can no longer be rejected. ${ }^{14}$

To what extent is nominal inertia in the $\mathrm{RH}$ associated with real income losses? Column 7 of Table 3 indicates that in the first post-shock period the real income loss resulting from disequilibrium is quite considerable (52 percent). Yet, due to the relatively quick adjustment of nominal prices after this period, the real income loss declines substantially and after the fifth post-shock period it is-except for period 10always below 10 percent. In the final periods the real income loss is always rather small which reflects the high incidence of equilibrium play.

The key difference between the RC and the $\mathrm{RH}$ is the presence of a relatively complex coordination problem in the RH. If subjects

\footnotetext{
${ }^{13}$ To prevent linear dependence among the set of regressors, we included no dummy variable for period 20 of the $\mathrm{RH}$.

${ }^{14} \mathrm{We}$ also examined the null hypothesis that prices in the $\mathrm{RH}$ differ from prices in the $\mathrm{RC}$ by means of nonparametric tests with individual data. The null hypothesis of equal price distributions and of equal average prices can be rejected for the first four post-shock periods at the 10percent level (Kolmogorov-Smirnov Test and MannWhitney Test).
}

Table 4-Deviation From Post-Shock Equilibrium in TREATMENTS WITH HuMAN OPPONENTS

\begin{tabular}{ccc}
\hline \hline $\begin{array}{l}\text { Post-Shock } \\
\text { Period }\end{array}$ & $\begin{array}{c}\text { Real Treatment with } \\
\text { Human Opponents } \\
(\mathrm{RH}) \text { Coefficient } \alpha_{t}\end{array}$ & $\begin{array}{c}\text { Nominal Treatment } \\
\text { with Human Opponents } \\
(\mathrm{NH}) \text { Coefficient } \beta_{t}\end{array}$ \\
\hline 1 & $3.10^{* * *}$ & $7.14^{* * * *}$ \\
2 & $1.68^{* *}$ & $6.86^{* * *}$ \\
3 & 1.43 & $5.43^{* * *}$ \\
4 & 0.90 & $4.41^{* * *}$ \\
5 & 1.00 & $3.86^{* * *}$ \\
6 & 0.55 & $4.18^{* * *}$ \\
7 & 0.25 & $3.77^{* * *}$ \\
8 & 0.35 & $3.05^{* * *}$ \\
9 & 0.25 & $2.70^{* * *}$ \\
10 & 0.83 & $2.59^{* * *}$ \\
11 & 0.13 & $2.05^{* * *}$ \\
12 & 0.23 & $1.61^{* *}$ \\
13 & 0.18 & 1.18 \\
14 & 0.18 & 0.89 \\
15 & 0.10 & 0.70 \\
16 & 0.13 & 1.25 \\
17 & 0.03 & 0.80 \\
18 & 0.13 & 1.20 \\
19 & 0.05 & 1.45 \\
20 & - & 0.95 \\
\hline
\end{tabular}

Notes: $\bar{P}_{i t}-\bar{P}_{1}^{*}=\sum_{t=1}^{19} \alpha_{t} d_{t}+\sum_{t=1}^{20} \beta_{t}\left(1-d_{t}\right)$. $d_{t}=1$ if price observation in period $t$ is from $\mathrm{RH}$

$* * *$ Denotes significance at the 1 -percent level.

**Denotes significance at the 5-percent level.

perceive coordination as a difficult problem this should be reflected in subjects' confidence in $\bar{P}_{-i}^{e}$. In the first few pre-shock periods, subjects' average confidence is at a level of 4 which means that they are, on average "quite confident." The high frequency of equilibrium play before the shock then causes a general increase in the confidence level. In the last five pre-shock periods, subjects exhibit, on average, a confidence level between 5 and 5.5. This means that most subjects are "very confident" (= level 5) or even "absolutely confident" (= level 6) that they have correct expectations. The anticipated negative money shock causes, however, a considerable decrease in subjects' confidence. In the first post-shock period, subjects are on average "not quite confident" (level 3) or "quite confident" (level 4) that their expectations will be correct. It takes about eight periods until pre-shock confidence levels are again established. This indicates that the money shock indeed causes a considerable coordination problem for the subjects.

Taken together, the evidence suggests that 
the introduction of a coordination problem in the real treatment causes initially a nonnegligible amount of nominal inertia that is associated with considerable real effects. Yet, nominal inertia vanishes relatively quickly so that already after a few periods prices are quite close to the equilibrium.

\section{Coordination in the Presence of Money Illusion}

Nominal inertia in the $\mathrm{RH}$ has nothing to do with money illusion but is caused by the problem to coordinate expectations and actions on the new equilibrium. From the comparison between the $\mathrm{RC}$ and the $\mathrm{NC}$ we already know that individual-level money illusion has a small positive effect on nominal inertia. In the $\mathrm{NH}$ a small amount of individual-level money illusion may, however, cause important indirect effects. These indirect effects can arise because the presence of individual-level money illusion is likely to affect subjects' expectations, which in turn affect their behavior. If money illusion indeed causes such indirect effects we should observe that the introduction of the nominal frame has a larger effect in the setting with human players than in the setting with computerized players. We should, in addition, also observe that in the setting with human players the nominal frame gives rise to an increase in the stickiness of subjects' price expectations.

Figure 1 and Table 3 (columns 3 and 4) provide the relevant information regarding the impact of the nominal frame. They show that nominal prices are indeed much stickier in the $\mathrm{NH}$ compared to the RH. In the final pre-shock period the overwhelming majority of the subjects play exactly the equilibrium both in the $\mathrm{RH}$ (93 percent) and the NH (80 percent). Therefore, average prices are very close to the pre-shock equilibrium $\bar{P}_{0}^{*}=18$. In the first post-shock period, however, only 11.5 percent of all subjects in the $\mathrm{NH}$ play exactly the equilibrium and 73 percent of the subjects are three or more price units above the equilibrium. In contrast, in the RH, 35 percent play exactly the equilibrium and, in addition, 23 percent are only two or less price units above the new equilibrium. These treatment differences in individual adjustment behavior also give rise to large differences in the average price level. In the first post-shock period the average price in the $\mathrm{NH}$ is 7.1 units above the equilibrium while in the $\mathrm{RH}$ the deviation is only 3.1 units (see Table 3 ). It takes eight periods in the $\mathrm{NH}$ until the deviation of average prices from equilibrium decreases to 3.1 units. These large differences in price adjustment speed are also confirmed by formal statistical tests. Table 4 reveals that in the $\mathrm{NH}$ the hypothesis of equilibrium play can be rejected at the 5-percent level for the first 12 post-shock periods while in the RH it can only be rejected for two periods. Similar results emerge when we examine the null hypothesis of equal average prices in the $\mathrm{NH}$ and the $\mathrm{RH}$ by means of a nonparametric Mann-Whitney Test with individual data. For the first nine postshock periods the null hypothesis can be rejected already at the 2-percent level. For the next three post-shock periods it can be rejected at the 10-percent level.

To what extent is nominal inertia in the $\mathrm{NH}$ associated with real income losses? Column 8 of Table 3 indicates that shortly before the shock, subjects in the $\mathrm{NH}$ achieve almost full efficiency. The monetary shock leads, however, to a substantial real income loss. In the first period after the shock the average income loss is 65 percent and during the first ten post-shock periods the loss is never below 9.5 percent. Note also that throughout the whole post-shock period the income loss is in general much higher in the $\mathrm{NH}$ than in the $\mathrm{RH}$ which is a consequence of the much stickier prices in the NH. For example, in the first ten post-shock periods of the $\mathrm{NH}$, the aggregate real income loss is roughly twice as large as the loss in the RH. In total, groups in the $\mathrm{NH}$ lose 26 percent of the potential payoff in the first ten post-shock periods. In the $\mathrm{RH}$, the respective losses are slightly less than 14 percent. Thus, the evidence clearly indicates two results: (i) In the setting with human players the introduction of a nominal frame has large and long-lasting effects on price stickiness. (ii) This increase in price stickiness is associated with a considerable increase in the real income loss caused by the anticipated money shock.

From Figure 1 and Table 3 we also can infer that the nominal frame causes much stickier prices when money illusion can have indirect effects. Throughout the first ten post-shock periods the adjustment difference in average prices between the NH and the RH, $\Delta P^{N H}-\Delta P^{R H}=P^{N H}-$ $P^{R H}$, is between two and 13 times larger than the 
adjustment difference between the $\mathrm{NC}$ and the $\mathrm{RC}, \Delta P^{N C}-\Delta P^{R C}=P^{N C}-P^{R C}$. It is, for example, easy to infer from Table 3 that, in the second post-shock period, the adjustment difference between the $\mathrm{NH}$ and the $\mathrm{RH}$ is $12.9-7.7=$ 5.2 price units, while the difference between the $\mathrm{NC}$ and the RC is only $7.4-7.0=0.4$ units. Hence, in this period the impact of the nominal frame is 13 times larger in the setting with human players compared to the setting with computerized players. In the tenth post-shock period the adjustment difference is still 1.8 units in the setting with human players and only 0.6 units in the setting with computerized players. To substantiate the indirect effects of money illusion we also conducted period-wise $t$-tests for the null hypothesis that the adjustment difference between the $\mathrm{NH}$ and the $\mathrm{RH}$ is bigger than between the $\mathrm{NC}$ and the RC. In five of the first ten post-shock periods the difference between the $\mathrm{NH}$ and the $\mathrm{RH}$ is significantly larger at the 5-percent level. In view of the considerable variance across the four conditions this is quite remarkable. ${ }^{15}$ Thus, the implementation of the nominal frame has a much larger impact in the setting where money illusion can also have indirect effects.

If money illusion has indirect effects we should also observe that expectations are stickier in the $\mathrm{NH}$ compared to the RH. Figure 2 shows the evolution of the average price expectations over time in both treatments. The figure shows that in the last few pre-shock periods, expectations are in equilibrium in both treatments. In the post-shock phase there are, however, striking differences. While expectations are very sticky in the NH they are far less sticky in the RH. To provide statistical evidence for this, we ran the same regression as in Table 4 with expectations data. It turns out that, in the $\mathrm{NH}$, expectations differ significantly from the equilibrium (at $p<0.05$ ) for 13 periods while in the RH they differ only for three periods. Thus, there can be little doubt that the nominal frame causes a large increase in the stickiness of price expectations. The next question then is, to what extent this difference in expectations causes differences in subjects' price choices. Or

\footnotetext{
15 There are two subjects in the NC condition who could well be classified as outliers. If we run the tests without these two subjects the indirect effects are highly significant in the first nine post-shock periods.
}

put differently, to what extent did subjects play a best reply to their expectations. The vast majority of subjects in both treatments indeed played best replies to $\bar{P}_{-i}^{e}$. During the first ten post-shock periods 84 percent of the subjects in the RH choose exactly the payoff-maximizing price in response to $\bar{P}_{-i}^{e}$ and the rest of the subjects chooses prices that were close to the best reply. In the $\mathrm{NH}$ there are slightly fewer subjects ( 80 percent) who chose exact best replies during the first ten post-shock periods. Yet, as in the $\mathrm{RH}$, the deviations from the exact best reply were in general very small. The fact that most subjects responded to $\bar{P}_{-i}^{e}$ with a payoff-maximizing price choice suggests that the greater stickiness of the expectations in the $\mathrm{NH}$ also caused a greater stickiness of actual prices in the $\mathrm{NH}$.

\section{Nominal Inertia after a Positive Money Shock}

\section{A. The Relevance of a Positive Money Shock}

Our results so far indicate that the direct effects of individual-level money illusion are relatively small. The introduction of the nominal frame in the setting with computerized players leads only to a small increase in nominal inertia. Nominal inertia is much more pronounced, however, when money illusion can also affect players' expectations and can, thus, also have indirect effects. In the NH, subjects' expectations are much stickier and, as a consequence, prices are much stickier. This raises the question of why expectations are so sticky in the NH compared to the $\mathrm{RH}$. We believe that the answer to this question can be found in the existence of subjects who take nominal payoffs as a proxy for real payoffs. Subjects who apply this rule of thumb mistakenly believe that if all players choose relatively high prices, all will reap high real payoffs because they all reap high nominal payoffs. They mistakenly believe that there are real gains from jointly setting high prices. Such subjects will, therefore, be reluctant to cut their nominal prices after the negative money shock in the NH. Moreover, if the presence of subjects who are reluctant to cut prices is anticipated by other subjects, others will be induced to cut their price insufficiently also.

It is important to note that the above rule of 


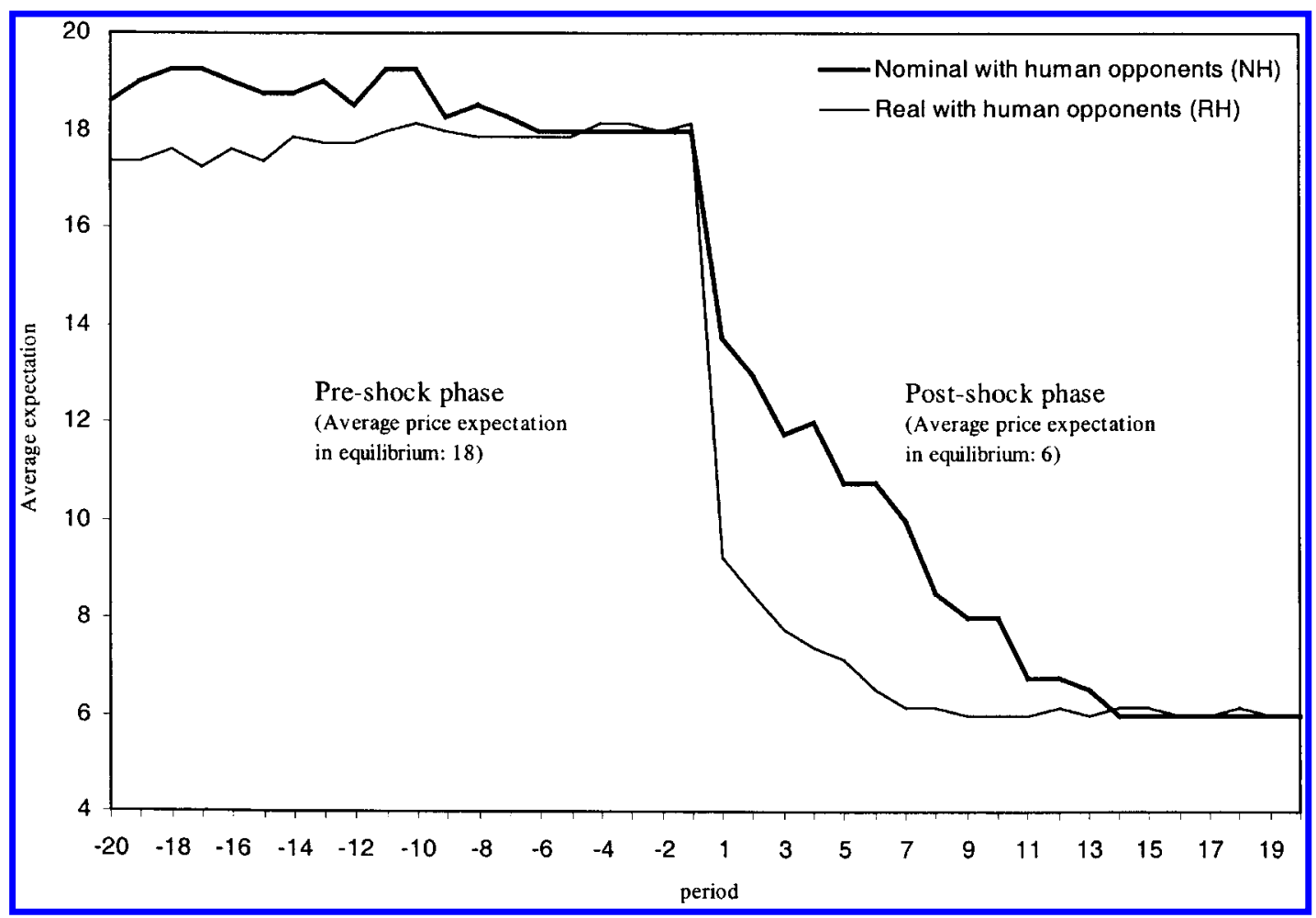

Figure 2. Evolution of Average Expectations

thumb cannot become effective in the RH. In the RH the numbers in the payoff tables represent real payoffs which makes it completely transparent that at high nominal prices real payoffs are not generally higher. This means that the presence of subjects who take nominal payoffs as a proxy for real payoffs causes no reluctance to cut nominal prices after the negative shock in the RH. These differences between the $\mathrm{NH}$ and the RH in the reluctance to cut nominal prices also provide a rationale for the much stickier price expectations in the $\mathrm{NH}$.

Yet, if the above explanation for the stickier expectations in the $\mathrm{NH}$ is correct, we should also observe that after a positive money shock, prices and expectations adjust more quickly to the equilibrium than after a negative shock. This is so because after a positive shock, adjustment towards equilibrium means adjustment towards higher prices and, hence, higher nominal payoffs. A quicker adjustment after a positive shock, however, does not mean that money illusion is absent when a positive shock occurs. It only means that money illusion has a different impact after a positive shock compared to a negative shock. After a negative shock the rule of thumb mentioned above causes a reluctance to adjust prices (downwards) while after a positive shock it does not cause a reluctance to adjust prices (upwards). Note further that while the rule of thumb implies a quicker adjustment to equilibrium after a positive shock in the $\mathrm{NH}$, the adjustment speed in the RH should not differ across positive and negative shocks. The reason is that the rule of thumb cannot become operative in the RH.

To test these implications of our explanation for the much stickier expectations in the $\mathrm{NH}$ we conducted additional experiments with a positive money shock. Forty-eight subjects (12 groups) participated in the $\mathrm{RH}$ and another 48 subjects (12 groups) participated in the NH with the positive money shock. The easiest way to implement a positive shock would be a reversal in the sequence of the money supply in our previous design. Unfortunately, this approach is 
not reasonable because the number of dominated strategies is much larger in the pre-shock phase than in the post-shock phase. Therefore, the indirect effects of money illusion can play a much smaller role in the pre-shock phase. The fact that prices in the $\mathrm{NH}$ adjust much more quickly to the equilibrium in the pre-shock phase than in the post-shock phase (see Figure 1 ) is consistent with this argument. Therefore, if we just reversed the sequence of the money supply, we would probably observe that adjustment is indeed quicker after the positive shock. Yet, this increase in the adjustment speed would not count as evidence for our explanation of the stickier expectations in the $\mathrm{NH}$.

What is, therefore, needed, is an experimental design in which the number of dominated strategies is roughly the same after the negative and after the positive shock. Our parameterization of the design with the positive shock serves this purpose. Except for three aspects, all experimental details in the positive-shock design are identical to the negative-shock design. In particular, all five features of the payoff functions, as described in Section II, subsection B, are also present in the positive-shock design. The differences are the following: (i) We did not implement computerized players in the positive-shock design because the main purpose of this design was to observe whether the expectations of human players and, hence, also prices adjust more quickly to the equilibrium after a positive shock compared to the negative shock. (ii) In the positive-shock design the pre- and the post-shock phase consisted of 15 instead of 20 periods. This shortening of the phases was implemented because in the negative-shock design reliable equilibration was already achieved after $10-15$ periods. (iii) To achieve roughly the same number of dominated strategies in the post-shock phase, equilibrium prices for $x$ - and $y$-types in the positive-shock design were as follows: The pre-shock equilibrium price for $x$-types ( $y$-types) is $P_{x}^{*}=11$ $\left(P_{y}^{*}=14\right)$ and the post-shock equilibrium price is $P_{x}^{*}=22\left(P_{y}^{*}=28\right)$. As a consequence, the average pre-shock equilibrium price in a group is $\bar{P}_{0}^{*}=12.5$ while in the post-shock equilibrium it is $\bar{P}_{1}^{*}=25$. Thus, the difference in average prices between preand post-shock equilibrium is 12.5 in the positive-
Table 5-Evolution of Prices And Efficiency Losses over TIME: Positive SHOck

\begin{tabular}{|c|c|c|c|c|}
\hline \multirow[b]{2}{*}{ Period } & \multicolumn{2}{|c|}{ Average Price } & \multicolumn{2}{|c|}{$\begin{array}{l}\text { Average Efficiency } \\
\text { Loss (Percent) }\end{array}$} \\
\hline & $\begin{array}{l}\text { Real } \\
\text { (RH) }\end{array}$ & $\begin{array}{l}\text { Nominal } \\
(\mathrm{NH})\end{array}$ & $\begin{array}{l}\text { Real } \\
\text { (RH) }\end{array}$ & $\begin{array}{c}\text { Nominal } \\
(\mathrm{NH})\end{array}$ \\
\hline-15 & 13.0 & 14.9 & 14.7 & 26.3 \\
\hline-14 & 13.0 & 14.7 & 18.2 & 24.7 \\
\hline-13 & 12.7 & 14.6 & 10.7 & 20.7 \\
\hline-12 & 12.7 & 14.3 & 5.3 & 13.6 \\
\hline-11 & 12.7 & 14.3 & 6.1 & 20.5 \\
\hline-10 & 12.5 & 14.1 & 1.6 & 9.1 \\
\hline-9 & 12.5 & 13.6 & 2.1 & 10.9 \\
\hline-8 & 12.5 & 13.4 & 0.3 & 11.3 \\
\hline-7 & 12.4 & 13.7 & 1.2 & 14.8 \\
\hline-6 & 12.5 & 13.8 & 0.6 & 13.2 \\
\hline-5 & 12.5 & 13.8 & 1.6 & 8.4 \\
\hline-4 & 12.5 & 13.9 & 0.3 & 10.4 \\
\hline-3 & 12.5 & 13.6 & 0.9 & 7.0 \\
\hline-2 & 12.6 & 13.1 & 4.7 & 6.9 \\
\hline-1 & 12.5 & 13.1 & 1.9 & 1.0 \\
\hline 1 & 22.5 & 20.5 & 22.3 & 24.0 \\
\hline 2 & 24.3 & 22.8 & 3.9 & 7.2 \\
\hline 3 & 24.8 & 24.1 & 1.2 & 4.2 \\
\hline 4 & 24.9 & 24.8 & 0.7 & 1.4 \\
\hline 5 & 25.0 & 25.0 & 0.2 & 0.9 \\
\hline 6 & 25.0 & 25.1 & 0.1 & 0.3 \\
\hline 7 & 25.0 & 25.2 & 0.1 & 0.4 \\
\hline 8 & 25.0 & 25.1 & 0.1 & 0.1 \\
\hline 9 & 25.0 & 25.0 & 0.1 & 0.1 \\
\hline 10 & 25.0 & 25.2 & 0.1 & 0.3 \\
\hline 11 & 25.0 & 25.2 & 0.2 & 0.1 \\
\hline 12 & 25.0 & 25.0 & 0.1 & 0.1 \\
\hline 13 & 25.0 & 25.0 & 0.1 & 0.1 \\
\hline 14 & 24.3 & 24.5 & 6.3 & 5.9 \\
\hline 15 & 24.6 & 24.9 & 4.0 & 1.4 \\
\hline
\end{tabular}

shock design while it is 12 in the negative-shock design. This slightly bigger adjustment requirement in the positive-shock design is, however, not a problem. If adjustment to equilibrium in the $\mathrm{NH}$ is faster after the positive shock, this is even more remarkable because it occurs despite the slightly bigger adjustment requirement in the positive-shock design.

\section{B. Prices and Expectations after the Positive Nominal Shock}

Table 5 shows the evolution of pre- and post-shock average prices in the $\mathrm{RH}$ and the $\mathrm{NH}$. In the $\mathrm{NH}$ pre-shock prices converge from above to the equilibrium $\bar{P}_{0}^{*}=12.5$ and as in the negative-shock design the vast ma- 


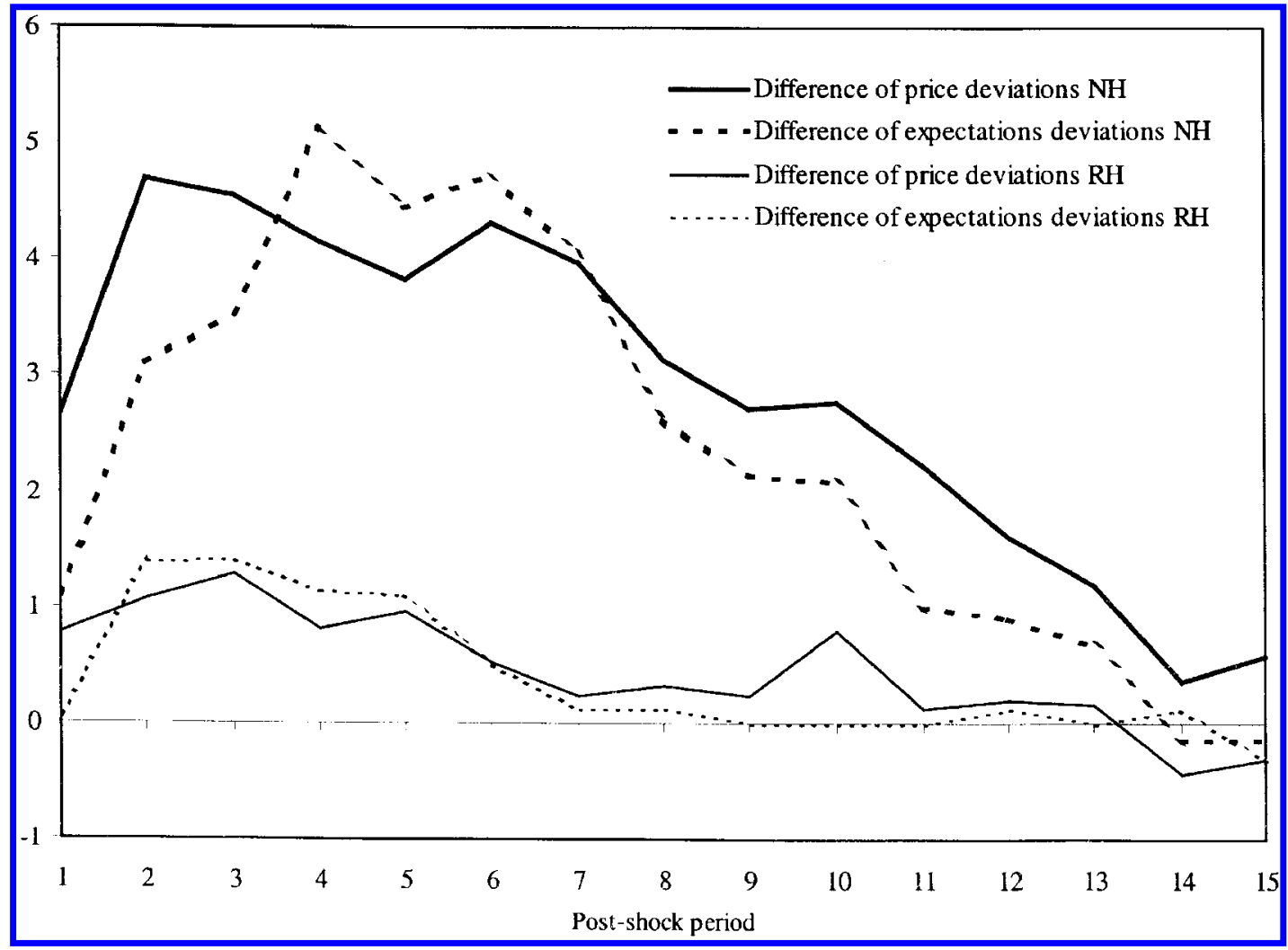

Figure 3. Differences in Deviations from Equilibrium Across the Negative and the Positive Shock

jority of individuals plays exactly the equilibrium in the final pre-shock period. Then, in the first post-shock period prices make a big jump upwards to 20.5 and already in period 4 after the shock, average prices are almost exactly at the new equilibrium of $\bar{P}^{*}=25$. From that period onwards prices remain very close to the equilibrium. This contrasts sharply with the adjustment process after the negative shock where, throughout the whole post-shock period, average prices never came so close to the equilibrium. This difference in $\mathrm{NH}$ adjustment paths after the negative and the positive shock is depicted in Figure 3. The heavy line in Figure 3 shows the difference in the post-shock deviations of average prices from the equilibrium between the positive and the negative shock. ${ }^{16}$ The graph reveals to what extent in the $\mathrm{NH}$ the adjustment gap, i.e., the deviation of average prices from the equilibrium, is larger after the negative shock than after the positive shock. It shows that the deviation from equilibrium is substantially larger after the negative shock. Between period 2 and 7, e.g., the adjustment gap is four or more units bigger after the negative shock. Even in period 10 the adjustment gap is still almost three units bigger.

The impression conveyed by Figure 3 is confirmed by a more formal statistical analysis. If we perform regression (3) with the data after the positive shock, it turns out that in the $\mathrm{NH}$ the

\footnotetext{
${ }^{16}$ Let $\bar{P}_{1+}^{*}$ be the post-shock equilibrium price in the positive-shock design and let $\bar{P}_{+}$be the actual post-shock average price. Analogously, let $\bar{P}_{-}$be the actual post-shock average price in the negative-shock design and denote the post-shock equilibrium price in this design by $\bar{P}_{1=}^{*}$. Then the heavy line in Figure 3 is given by $\left(\bar{P}_{-}-\bar{P}_{1-}^{*}\right)-$ $\left(\bar{P}_{1+}^{*}-\bar{P}_{+}\right)$, which measures the difference in the average deviations from equilibrium across the positive and the negative shock for the first 15 periods of the post-shock phase in the $\mathrm{NH}$.
} 
hypothesis of equilibrium play can only be rejected for the first three periods (at the 5-percent level). Remember that after the negative shock, group prices were significantly above the equilibrium for 12 periods. Thus, the evidence unambiguously indicates that adjustment in the $\mathrm{NH}$ is much quicker after the positive shock, which is consistent with our hypothesis that there is less reluctance against adjustment after the positive shock.

If there is indeed less reluctance against adjustment after the positive shock, at least some subjects should anticipate this. Therefore we should also observe that expectations are less sticky after the positive shock. The dashed heavy line in Figure 3 shows the difference in the post-shock deviations of the average expectations of $\bar{P}_{-i}$ from the equilibrium between the positive and the negative shock. This graph is constructed analogously to the heavy line in Figure 3 except that we used the expectations $\bar{P}_{-i}^{e}$ to construct it. Thus the dashed heavy line shows to what extent the adjustment gap in the expectations, i.e., the deviation of average expectations from equilibrium, is larger after the negative shock than after the positive one. The graph indicates that the adjustment gap in the expectations is much larger after the negative shock for many time periods. Interestingly, the graph is hump-shaped, i.e., the relative stickiness of expectations after the negative shock increases in the first few periods. This is due to the fact that between period 2 and 5 after the positive shock, expectations rapidly converge to equilibrium while they are very sticky after the negative shock.

Finally, since the rule of thumb of taking nominal payoffs as a proxy for real payoffs cannot be operative in the RH, we should observe no differences in price adjustment in the RH across negative and positive shocks. Table 5 shows the evolution of average prices in the RH after the positive shock and Figure 3 illustrates the differences in average prices and average expectations across shocks. Table 5 indicates that in the pre-shock phase of the $\mathrm{RH}$ the average price is very close to the equilibrium $\bar{P}_{0}^{*}=12.5$ already after three periods. Immediately after the positive shock there is a big upward jump in prices to 22.5 , only 2.5 units below the new equilibrium. Already in the third post-shock period the average price is again very close to the equilibrium. This indicates that price adjustment after the positive shock is rather quick in the $\mathrm{RH}$ - similar to the pattern after the negative shock. This similarity is also displayed in Figure 3 and by formal statistical analysis. The thin line in Figure 3 is constructed analogously to the heavy line except that we use the price data from the $\mathrm{RH}$. It shows that price adjustment in the RH is only slightly faster after the positive shock. If we perform regression (3) with the post-shock data from the positive-shock design we get the following results: The hypothesis that average prices in the $\mathrm{RH}$ are in equilibrium can only be rejected for the first two periods (at the 5-percent level). Note that this is exactly the same number of out-of-equilibrium periods as after the negative shock. This suggests that the differences in the price adjustment across shocks in the $\mathrm{RH}$ are indeed negligible. The dashed thin line in Figure 3, which is constructed analogously to the dashed heavy line except that we use the expectations data from the RH, indicates that we can basically make a similar conclusion with regard to the differences in the adjustment of expectations across shocks. While in the NH there are large differences in the stickiness of expectations across shocks, in the RH the differences in expectations are rather small.

Thus all major regularities are consistent with our hypothesis that there are beliefs that some subjects take nominal payoffs as a proxy for real payoffs. Nonetheless, it would be reassuring if subjects themselves expressed such a belief. To check to what extent subjects indeed believed this they could indicate their degree of agreement with the following statement after the experiment: "I believed that the other subjects would interpret high nominal payoffs as an indicator for high real payoffs." Participants could indicate whether they weakly (dis)agreed, whether they strongly (dis)agreed or whether they totally (dis)agreed with this statement. Thirty percent of the subjects in the NH agreed either "strongly" or "totally" and further 25 percent indicated a weak agreement. In our view, this can be taken as direct evidence that a majority of the subjects believed that other subjects were affected by money illusion. In 
any case, these answers nicely fit with our explanation for the large amount of nominal inertia observed in the NH after the negative shock.

\section{Summary and Concluding Remarks}

Most economic transactions are represented in nominal terms. Therefore, it seems likely that people often perceive and think about economic problems in nominal terms which may induce money illusion. However, for several decades money illusion has been considered as largely irrelevant for the nominal inertia of aggregate price levels. Instead, most economists have focused on informational frictions, costs of price adjustment, and staggered contracts. This paper shows, however, that even in the absence of these factors a fully anticipated negative nominal shock can cause long-lasting nominal inertia that is associated with large real income losses during the adjustment phase. Our results indicate that a large part of this nominal inertia can be attributed to the direct and indirect effects of money illusion. The experiments in the setting with computerized opponents show that the direct effects of money illusion in the form of individual optimization mistakes are not very frequent: The introduction of the nominal frame in the setting with computerized opponents causes only a small amount of nominal inertia. However, the combined direct and indirect effects of money illusion generate a very large increase in nominal inertia. This is indicated by the fact that the introduction of the nominal frame in the setting with human opponents causes a huge increase in the sluggishness of prices. Instead of two it takes 12 periods until average prices reach the post-shock equilibrium in this setting.

The major cause for nominal inertia after the negative shock is that subjects' expectations are very sticky. In our view this stickiness of price expectations is related to the nature of money illusion in our experiment, i.e., to the belief that there are subjects who take nominal payoffs as a proxy for real payoffs. This conjecture is supported by direct questionnaire evidence and by the results of further experiments with a fully anticipated positive nominal shock. It turns out that price sluggishness is much smaller after a positive nominal shock than after the negative shock. This result is also interesting insofar as there is field evidence indicating that positive and negative money shocks have asymmetric effects. While negative shocks have an outputreducing effect, positive shocks do not seem to affect output (James Peery Cover, 1992; J. Bradford DeLong and Lawrence H. Summers, 1988). The asymmetric effects of money illusion on price sluggishness can be considered as a potential microfoundation for this result.

Finally, another interesting result of our experiments is that we isolate-in addition to money illusion - a further source of nominal inertia. This source is related to the fact that in a strategic situation subjects do not merely face an individual optimization problem but that they also have to predict other agents' behavior. After any shock, the new equilibrium can only be achieved if subjects have coordinated (equilibrium) expectations. The comparison of adjustment paths in the real treatments with computerized and with human opponents shows that after a fully anticipated nominal shock, it cannot be taken for granted that subjects instantaneously succeed in solving this coordination problem. They will, in general, go through a period of disequilibrium that is associated with nominal inertia. Note, however, that the coordination problem alone causes substantially less nominal inertia than money illusion. It also does not cause asymmetric effects: In the real treatment with human opponents the extent of nominal inertia is very similar after the positive and the negative nominal shock.

These results show that experiments can be a useful tool for the examination of the nature, the extent, and the impact of money illusion in strategic economic interactions. There are many other questions that could be usefully tackled by experimental methods. One open question is how subjects who are familiar with money shocks in our pricing game will respond to new shocks. Future research should thus examine how the adjustment pattern varies when experienced subjects face a series of different shocks. Other interesting questions concern the nature of nominal wage rigidity and the interaction of price and wage policies during adjustment. To answer these questions it is necessary to introduce workers as separate players in the game. The analysis of the interaction between wage and price setting may prove particularly useful because there are likely to be strong 
natural complementarities. For example, if firms anticipate that workers will resist wage cuts after a negative money shock they will probably be reluctant to cut prices because this would reduce their profits. Yet, if prices stay high, workers may feel justified in resisting wage cuts. Thus, the reluctance to cut wages and prices could be mutually reinforcing for an extended period of time. Finally, another interesting question concerns how the impact of money illusion varies with the degree of strategic complementarity. Is a lower degree of complementarity associated with less aggregate nominal inertia or not? Or, more fundamentally, does the impact of money illusion vanish in an environment with strategic substitutability?

In our view the results of our experiments indicate that money illusion should be considered as a serious candidate in the explanation of nominal inertia and the real effects of nominal shocks. Paraphrasing Abraham Lincoln, ${ }^{17}$ one can say that, to render money illusion behaviorally relevant, it is not necessary to fool all the people some of the time, not to speak of fooling all the people all the time. All that is needed is an environment with strategic complementarity and the presence of a small amount of money illusion at the individual level-a presupposition that seems quite plausible.

\section{ApPendix: Payoff Functions}

As explained in detail in Section II, subsections $\mathrm{B}$ and $\mathrm{C}$, payoffs were presented to subjects in payoff tables. These tables were calculated from the payoff functions explained below. A full set of payoff tables is contained in Fehr and Tyran (2000) which can be downloaded from http://www.iew.unizh.ch/wp/iewwp045.pdf. The payoff tables are also available from the authors upon request.

The real payoff for agent $i$ of type $k=x, y$ is given by:

$$
\pi_{i k}=\frac{V \cdot\left[\frac{1+a \cdot \Delta^{2}}{1+b \cdot \Delta^{2}}\right]}{1+c \cdot\left[\left(\frac{P_{i k}}{M}-\frac{P_{k}^{*}}{M}\right)-d \cdot \Delta+e \cdot \arctan (f \cdot \Delta)\right]^{2}}
$$

$\bar{P}_{-i k}$ is the actual average price of the other $n-1$ players from the viewpoint of player $i$ who is of type $k . \bar{P}_{k}^{*}$ is the equilibrium average price of the other $n-1$ players from the viewpoint of a player of type $k . P_{i k}$ is the actual price of $i$ who is of type $k . P_{k}^{*}$ is the equilibrium price of a player of type $k$. Finally, $\Delta=\left(\bar{P}_{-i k} / M\right)-\left(\bar{P}_{k}^{*} / M\right)$. The parameters for $M$ and all equilibrium values can be found in Table 2.

In all periods and all experimental sessions

\footnotetext{
${ }^{17}$ In his speech on September 8, 1858, Lincoln said: "You can fool all the people some of the time, and some of the people all the time, but you cannot fool all the people all the time."
}

the parameters $a, b, c, d, e, f$, and $V$ were the same. They were given by $a=0.5, b=0.6$, $c=27, d=1, e=0.05, f=20$ and $V=40$.

\section{REFERENCES}

Abbott, Michael and Ashenfelter, Orley. "Labour Supply, Commodity Demand and the Allocation of Time." Review of Economic Studies, October 1976, 43(3), pp. 389-411.

Akerlof, George A.; Dickens, Williams T. and Perry, George L. "The Macroeconomics of Low Inflation." Brookings Papers on Economic Activity, 1996, (1), pp. 1-59.

Akerlof, George A. and Yellen, Janet L. "A Nearrational Model of the Business Cycle, with 
Wage and Price Inertia." Quarterly Journal of Economics, 1985, Supp., 100(5), pp. 82338.

Belongia, Michael T. "Measurement Matters: Recent Results from Monetary Economics Reexamined." Journal of Political Economy, October 1996, 104(5), pp. 1065-83.

Bernanke, Ben S. and Carey, Kevin. "Nominal Wage Stickiness and Aggregate Supply in the Great Depression." Quarterly Journal of Economics, August 1996, 111(3), pp. 85383.

Bewley, Truman F. "Why Not Cut Pay?" European Economic Review, May 1998, 42(3-5), pp. 459-90.

Blanchard, Olivier Jean. "Why Does Money Affect Output? A Survey," in Benjamin M. Friedman and Frank H. Hahn, eds., Handbook of monetary economics, Vol. 2. Amsterdam: North-Holland, 1990, pp. 779835.

Blanchard, Olivier Jean and Kiyotaki, Nobuhiro. "Monopolistic Competition and the Effects of Aggregate Demand." American Economic Review, September 1987, 77(4), pp. 647-66.

Blanchard, Olivier Jean and Summers, Lawrence H. "Hysteresis and the European Unemployment Problem," in Stanley Fischer, ed., NBER macroeconomics annual 1986. Cambridge, MA: MIT Press, 1986, pp. 15-78.

Blinder, Alan S.; Canetti, Elie D.; Lebow, David E. and Rudd, Jeremy B. Asking about prices: A new approach to understanding price stickiness. New York: Russell Sage Foundation, 1998.

Card, David and Hyslop, Dean. "Does Inflation 'Grease the Wheels of the Labor Market'?" in Christina D. Romer and David H. Romer, eds., Reducing inflation: Motivation and strategy. NBER Studies in Business Cycles, Vol. 30. Chicago: University of Chicago Press, 1997, pp. 71-114.

Coleman, Wilbur John. "Money and Output: A Test of Reverse Causation." American Economic Review, March 1996, 86(1), pp. 90-111.

Cooper, Russell W. Coordination games: Complementarities and macroeconomics. Cambridge, MA: Cambridge University Press, 1999.

Cooper, Russell and Haltiwanger, John. "Evidence on Macroeconomic Complementari- ties." Review of Economics and Statistics, February 1996, 78(1), pp. 78-93.

Cover, James Peery. "Asymmetric Effects of Positive and Negative Money-Supply Shocks." Quarterly Journal of Economics, November 1992, 107(4), pp. 1261-82.

DeLong, J. Bradford and Summers, Lawrence $H$. "How Does Macroeconomic Policy Affect Output?" Brookings Papers on Economic Activity, 1988, (2), pp. 433-80.

Diamond, Peter A. "Aggregate Demand Management in Search Equilibrium." Journal of Political Economy, October 1982, 90(5), pp. 881-94.

Evans, George W. and Ramey, Garey. "Expectation Calculation and Macroeconomic Dynamics." American Economic Review, March 1992, 82(1), pp. 207-24.

. "Calculation, Adaptation and Rational Expectations." Macroeconomic Dynamics, June 1998, 2(2), pp. 156-82.

Fehr, Ernst and Tyran, Jean-Robert. "Does Money Illusion Matter?" Working Paper No. 45, Institute for Empirical Research in Economics, University of Zurich, 2000.

Fischer, Stanley. "Long-Term Contracts, Rational Expectations, and the Optimal Money Supply Rule." Journal of Political Economy, February 1977, 85(1), pp. 191-205.

Fisher, Irving. The money illusion. Toronto: Longmans, 1928.

Friedman, Benjamin M. and Hahn, Frank M., eds., Handbook of monetary economics, Vol. 2. Amsterdam: North-Holland, 1990.

Haltiwanger, John and Waldman, Michael. "Rational Expectations and the Limits of Rationality: An Analysis of Heterogeneity." American Economic Review, June 1985, 75(3), pp. 326-40.

. "Limited Rationality and Strategic Complements: The Implications for Macroeconomics." Quarterly Journal of Economics, August 1989, 104(3), pp. 463-83.

Hoover, Kevin D. and Perez, Stephen J. "Post Hoc Ergo Propter Once More: An Evaluation of 'Does Monetary Policy Matter?' in the Spirit of James Tobin." Journal of Monetary Economics, August 1994, 34(1), pp. 47-73.

Howitt, Peter. "Money Illusion," in John Eatwell, Murray Milgate, and Peter Newman, 
eds., Money. New York: Norton, 1989, pp. 244-47.

Kahn, Shulamit. "Evidence of Nominal Wage Stickiness from Microdata." American Economic Review, December 1997, 87(5), pp. 993-1008.

Leontief, Wassily. "The Fundamental Assumptions of Mr. Keynes' Monetary Theory of Unemployment." Quarterly Journal of Economics, November 1936, 5(4), pp. 192-97.

Lucas, Robert E., Jr. "Expectations and the Neutrality of Money." Journal of Economic Theory, April 1972, 4(2), pp. 103-24.

Mankiw, N. Gregory. "Small Menu Costs and Large Business Cycles: A Macroeconomic Model." Quarterly Journal of Economics, May 1985, 10(2), pp. 529-38.

Niemi, Beth T. and Lloyd, Cynthia B. "Female Labor Supply in the Context of Inflation." American Economic Review, May 1981 (Papers and Proceedings), 71(2), pp. 70-75.

Oh, Seonghwan and Waldman, Michael. "The Macroeconomic Effects of False Announcements." Quarterly Journal of Economics, November 1990, 105(4), pp. 1017-34. - "Strategic Complementarity Slows Macroeconomic Adjustment to Temporary Shocks." Economic Inquiry, April 1994, 32(2), pp. 318-29.

Patinkin, Don. "The Indeterminacy of Absolute Prices in Classical Economic Theory." Econometrica, January 1949, 17(1), pp. $1-27$.
Romer, Christina D. and Romer, David H. "Does Monetary Policy Matter? A New Test in the Spirit of Friedman and Schwartz," in Olivier Jean Blanchard and Stanley Fischer, eds., NBER macroeconomics annual: 1989. Cambridge, MA: MIT Press, 1989, pp. 121-70. . "Monetary Policy Matters." Journal of Monetary Economics, August 1994, 34(1), pp. 75-88.

Russell, Thomas and Thaler, Richard. "The Relevance of Quasi Rationality in Competitive Markets." American Economic Review, December 1985, 75(5), pp. 1071-82.

Selten, Reinhard and Berg, Claus C. "Drei Experimentelle Oligopolspielserien mit Kontinuierlichem Zeitablauf," in Heinz Sauermann, ed., Beiträge zur experimentellen Wirtschaftsforschung, Vol. II. Tübingen: 1970, pp. 162-221.

Shafir, Eldar; Diamond, Peter and Tversky, Amos. "Money Illusion." Quarterly Journal of Economics, May 1997, 112(2), pp. 34174.

Taylor, John B. "Staggered Wage Setting in a Macro Model." American Economic Review, May 1979 (Papers and Proceedings), 69(2), pp. $108-13$.

Tobin, James. "Inflation and Unemployment." American Economic Review, March 1972, 62(1), pp. 1-18.

Tversky, Amos and Kahneman, Daniel. "The Framing of Decisions and the Psychology of Choice." Science, January 1981, 211, pp. 453-58. 


\section{This article has been cited by:}

1. Heleen Mees, Philip Hans Franses. 2014. Are individuals in China prone to money illusion?. Journal of Behavioral and Experimental Economics . [CrossRef]

2. Luba Petersen, Abel Winn. 2014. Does Money Illusion Matter?: Comment†. American Economic Review 104:3, 1047-1062. [Abstract] [View PDF article] [PDF with links]

3. Ernst Fehr, Jean-Robert Tyran. 2014. Does Money Illusion Matter?: Reply†. American Economic Review 104:3, 1063-1071. [Abstract] [View PDF article] [PDF with links]

4. Gabriele Camera, Marco Casari. 2014. The Coordination Value of Monetary Exchange: Experimental Evidence†. American Economic Journal: Microeconomics 6:1, 290-314. [Abstract] [View PDF article] [PDF with links]

5. Stephen L. Cheung, Morten Hedegaard, Stefan Palan. 2014. To see is to believe: Common expectations in experimental asset markets. European Economic Review 66, 84-96. [CrossRef]

6. Fortuna Casoria, Arno RiedlExperimental Labor Markets and Policy Considerations: Incomplete Contracts and Macroeconomic Aspects 5-29. [CrossRef]

7. Tommy Gärling, Amelie Gamble, Fabian Christandl. 2013. Income increases do not compensate for perceived inflation-A price-consumption anomaly. The Journal of Socio-Economics 47, 11-15. [CrossRef]

8. Andreas Orland, Michael W.M. Roos. 2013. The New Keynesian Phillips curve with myopic agents. Journal of Economic Dynamics and Control 37:11, 2270-2286. [CrossRef]

9. Daniel John Zizzo. 2013. Claims and confounds in economic experiments. Journal of Economic Behavior \& Organization 93, 186-195. [CrossRef]

10. Fortuna Casoria, Arno Riedl. 2013. EXPERIMENTAL LABOR MARKETS AND POLICY CONSIDERATIONS: INCOMPLETE CONTRACTS AND MACROECONOMIC ASPECTS. Journal of Economic Surveys 27:3, 398-420. [CrossRef]

11. Johann Graf Lambsdorff, Manuel Schubert, Marcus Giamattei. 2013. On the role of heuristics -Experimental evidence on inflation dynamics. Journal of Economic Dynamics and Control 37:6, 1213-1229. [CrossRef]

12. D. Acker, N. W. Duck. 2013. Do Investors Suffer from Money Illusion? A Direct Test of the Modigliani-Cohn Hypothesis. Review of Finance 17:2, 565-596. [CrossRef]

13. Andrea Vaona. 2013. Money illusion and the long-run Phillips curve in staggered wage-setting models. Research in Economics 67:1, 88-99. [CrossRef]

14. Giuseppe Ciccarone, Enrico Marchetti. 2013. Rational expectations and loss aversion: Potential output and welfare implications. Journal of Economic Bebavior \& Organization 86, 24-36. [CrossRef]

15. Tomer Blumkin, Bradley J. Ruffle, Yosef Ganun. 2012. Are income and consumption taxes ever really equivalent? Evidence from a real-effort experiment with real goods. European Economic Review 56:6, 1200-1219. [CrossRef]

16. Te Bao, Cars Hommes, Joep Sonnemans, Jan Tuinstra. 2012. Individual expectations, limited rationality and aggregate outcomes. Journal of Economic Dynamics and Control 36:8, 1101-1120. [CrossRef]

17. William G. Hardin, Xiaoquan Jiang, Zhonghua Wu. 2012. REIT Stock Prices with Inflation Hedging and Illusion. The Journal of Real Estate Finance and Economics 45:1, 262-287. [CrossRef]

18. Charles N. Noussair, Gregers Richter, Jean-Robert Tyran. 2012. Money Illusion and Nominal Inertia in Experimental Asset Markets. Journal of Behavioral Finance 13:1, 27-37. [CrossRef] 
19. Douglas Davis, Oleg Korenok. 2011. Nominal shocks in monopolistically competitive markets: An experiment. Journal of Monetary Economics . [CrossRef]

20. Tobias F. Rötheli. 2011. THE SUPERIORITY OF MONETARY OVER BARTER EXCHANGE: EXPERIMENTAL RESULTS AND POLICY IMPLICATIONS. Scottish Journal of Political Economy 58:4, 437-454. [CrossRef]

21. Darren K. Hayunga, Peter P. Lung. 2011. Explaining Asset Mispricing Using the Resale Option and Inflation Illusion. Real Estate Economics no-no. [CrossRef]

22. Sacha Bourgeois-Gironde, Marianne Guille. 2011. Keynes's animal spirits vindicated: an analysis of recent empirical and neural data on money illusion. Journal of Post Keynesian Economics 34:2, 331-352. [CrossRef]

23. Guglielmo Maria Caporale, Alessandro Girardi, Marco Ventura. 2011. The euro changeover and price adjustments in Italy. Applied Economics Letters 1-4. [CrossRef]

24. Vivian Afi Abui Dzokoto, Edwin Clifford Mensah, Maxwell Twum-Asante, Annabella OpareHenaku. 2010. Deceiving Our Minds: A Qualitative Exploration of the Money Illusion in Postredenomination Ghana. Journal of Consumer Policy 33:4, 339-353. [CrossRef]

25. Maik Schmeling, Andreas Schrimpf. 2010. Expected inflation, expected stock returns, and money illusion: What can we learn from survey expectations?. European Economic Review . [CrossRef]

26. Tal Shavit, Cinzia Giorgetta, Yaniv Shani, Fabio Ferlazzo. 2010. Using an Eye Tracker to Examine Behavioral Biases in Investment Tasks: An Experimental Study. Journal of Behavioral Finance 11:4, 185-194. [CrossRef]

27. SULEYMAN BASAK, HONGJUN YAN. 2010. Equilibrium Asset Prices and Investor Behaviour in the Presence of Money Illusion. Review of Economic Studies 77:3, 914-936. [CrossRef]

28. David Ashton, Ken Peasnell, Pengguo Wang. 2010. Residual Income Valuation Models and Inflation. European Accounting Review 1-25. [CrossRef]

29. Ernst Fehr, Lorenz Goette, Christian Zehnder. 2009. A Behavioral Account of the Labor Market: The Role of Fairness Concerns. Annual Review of Economics 1:1, 355-384. [CrossRef]

30. Simon Gächter. 2009. Vorwort des Gastherausgebers Experimentelle Ökonomie: Neue Wege, neue Erkenntnisse?. Perspektiven der Wirtschaftspolitik 10, 1-13. [CrossRef]

31. B. Weber, A. Rangel, M. Wibral, A. Falk. 2009. The medial prefrontal cortex exhibits money illusion. Proceedings of the National Academy of Sciences 106:13, 5025-5028. [CrossRef]

32. Fabrizio Adriani, Giancarlo Marini, Pasquale Scaramozzino. 2009. The Inflationary Consequences of a Currency Changeover on the Catering Sector: Evidence from the Michelin Red Guide. Oxford Bulletin of Economics and Statistics 71:1, 111-133. [CrossRef]

33. Ernst Fehr, Jean-Robert Tyran. 2008. Limited Rationality and Strategic Interaction: The Impact of the Strategic Environment on Nominal Inertia. Econometrica 76:2, 353-394. [CrossRef]

34. RALPH-C. BAYER, MICKEY CHAN. 2007. Network Externalities, Demand Inertia and Dynamic Pricing in an Experimental Oligopoly Market*. Economic Record 83:263, 405-415. [CrossRef]

35. Peter Flaschel, Göran Kauermann, Willi Semmler. 2007. TESTING WAGE AND PRICE PHILLIPS CURVES FOR THE UNITED STATES. Metroeconomica 58:4, 550-581. [CrossRef]

36. Henrik Svedsäter, Amelie Gamble, Tommy Gärling. 2007. Money illusion in intuitive financial judgments: Influences of nominal representation of share prices. The Journal of Socio-Economics 36:5, 698-712. [CrossRef]

37. Peter P. Wakker, Veronika Köbberling, Christiane Schwieren. 2007. Prospect-theory's Diminishing Sensitivity Versus Economics' Intrinsic Utility of Money: How the Introduction of the Euro can be Used to Disentangle the Two Empirically. Theory and Decision 63:3, 205-231. [CrossRef] 
38. Christopher L. ERICKSON, Daniel J.B. MITCHELL. 2007. Monopsony as a metaphor for the emerging post-union labour market. International Labour Review 146:3-4, 163-187. [CrossRef]

39. Christopher L. ERICKSON, Daniel J. B. MITCHELL. 2007. Les nouveaux marchés du travail: monopsone et faiblesse syndicale. Revue internationale du Travail 146:3-4, 179-206. [CrossRef]

40. Christopher L. ERICKSON, Daniel J.B. MITCHELL. 2007. El monopsonismo, metáfora del nuevo mercado de trabajo postsindical. Revista Internacional del Trabajo 126:3-4, 185-212. [CrossRef]

41. Steven D. Levitt, John A. List. 2007. Viewpoint: On the generalizability of lab behaviour to the field. Canadian Journal of Economics/Revue canadienne d'économique 40:2, 347-370. [CrossRef]

42. Giancarlo Marini, Alessandro Piergallini, Pasquale Scaramozzino. 2007. Inflation bias after the Euro: evidence from the UK and Italy. Applied Economics 39:4, 461-470. [CrossRef]

43. Klaus Abbink, Heike Hennig-Schmidt. 2006. Neutral versus loaded instructions in a bribery experiment. Experimental Economics 9:2, 103-121. [CrossRef]

44. JANET L. YELLEN, GEORGE A. AKERLOF. 2006. STABILIZATION POLICY: A RECONSIDERATION. Economic Inquiry 44:1, 1-22. [CrossRef]

45. T SEHITY, E HOELZL, E KIRCHLER. 2005. Price developments after a nominal shock: Benford's Law and psychological pricing after the euro introduction. International Journal of Research in Marketing 22:4, 471-480. [CrossRef]

46. Ernst Fehr, Jean-Robert Tyran. 2005. Individual Irrationality and Aggregate Outcomes. Journal of Economic Perspectives 19:4, 43-66. [Abstract] [View PDF article] [PDF with links]

47. Oscar Bajo-Rubio, Carmen Díaz-Roldán, Vicente Esteve. 2005. Is the Fisher effect non-linear? some evidence for Spain, 1963-2002. Applied Financial Economics 15:12, 849-854. [CrossRef]

48. E FEHR, L GOETTE. 2005. Robustness and real consequences of nominal wage rigidity. Journal of Monetary Economics 52:4, 779-804. [CrossRef]

49. Thomas Beissinger, Chritoph Knoppik. 2005. Sind Nominallohne starr? Neuere Evidenz und wirtschaftspolitische Implikationen. Perspektiven der Wirtschaftspolitik 6:2, 171-188. [CrossRef]

50. Reto Schleiniger. 2005. Money Illusion and the Double Dividend in the Short Run. German Economic Review 6:2, 249-254. [CrossRef]

51. Rob Ranyard, Carole B. Burgoyne, Gabriela Saldanha, David A. Routh. 2005. A qualitative study of adaptation to the euro in the Republic of Ireland: I. attitudes, the ?euro illusion? and the perception of prices. Journal of Community \& Applied Social Psychology 15:2, 95-107. [CrossRef]

52. Roger Hosein, Timothy Michael Lewis. 2005. Quantifying the relationship between aggregate GDP and construction value added in a small petroleum rich economy - a case study of Trinidad and Tobago. Construction Management and Economics 23:2, 185-197. [CrossRef]

53. Mai Anttila. 2004. Consumer price perceptions after translation to Euro currency. Journal of Product \& Brand Management 13:1, 47-55. [CrossRef]

54. George A. Akerlof. 2002. Behavioral Macroeconomics and Macroeconomic Behavior. American Economic Review 92:3, 411-433. [Citation] [View PDF article] [PDF with links]

55. Pierre Desmet. 2002. A study of the potential effects of the conversion to euro. Journal of Product \& Brand Management 11:3, 134-146. [CrossRef] 